\title{
Some Elements of Knowledge on the Coastal Floristic Formations of Martinique (French West Indies)
}

\author{
Philippe Joseph $^{1}$ \& Kévine Baillard ${ }^{1}$ \\ ${ }^{1}$ University of the French West Indies-UMR SPACE DEV/BIORECA \\ Correspondence: Philippe Joseph, Université des Antilles pôle Martinique-97200. E-mail: \\ joseph.phil@wanadoo.fr
}

Received: March 12, 2017

Accepted: May 28, 2017

Online Published: June 5, 2017

doi:10.5539/jgg.v9n2p39

URL: http://dx.doi.org/10.5539/jgg.v9n2p39

\begin{abstract}
From the middle of the 17th century to the end of the 18th century, the dynamics of land use in Martinique were accompanied by significant landscape transformation. The latter resulted from profound changes in the structural and functional organization of the vegetation. In the end, the history of this small tropical island is a permanent process of biocenonic changes. Despite the limited available data, it is likely that these were accompanied by disappearances of species. This specific diversity erosion mainly concerns the species in the last phases of ecosystemic evolution: particularly those of climax formations. In reality, the successive Antillean societies, formerly agrarian and today characterized by a strong presence of tertiary activities, led to a marked decline in pre-Columbian forests, which are supposed to be primitive. Many coastline forests were soon eliminated. Apart from the very marginal climatic forests protected by the foothills of the Pitons du Carbet and the Pelee Mountain, the secondary forest formations occupy small areas. Isolated in a herbaceous, shrubby and pre-forest vegetation, whose surface is being inexorably reduced due to human activities, they occupy zones that are unsuitable for agriculture, habitation and the various vital infrastructures: slopes, valley or gully bottoms, narrow ridges. The coastline, which was the main settlement location for the first Caribbean societies, is still home to most of the population and economic activities. It is characterized by species, physiognomies and phytocenoses typical of artificialized biotopes. Faced with an inexorable societal development, how can we preserve the floristic, ecosystemic and coastal landscape diversity specific to the patrimonial forest formations which have become natural monuments?
\end{abstract}

Keywords: Martinique, coastline, ecosystem, flora, anthropisation

\section{Introduction}

The first people settled on the Lesser Antilles coasts and they still remain the preferred space for socio-economic development (Erlandson and Fitzpatrick, 2006, Loveless, 1960; Mokhtar, 2013; Siegel et al., 2015). In the French islands [French Department of America (DFA)] as in the rest of the archipelago, the spatial and ecosystemic regression of the pre-colonial vegetation is one of the main consequences (Meur-Ferec, Deboudt and Morel, 2008, Bonnissent et al., 1998, Joseph, 2015, Bertran et al., 2004). The few existing plant communities that recall those of the Amerindian times (Note 1) have become natural monuments (Joseph, 1997). Given their small spatial size and the characteristics of the land (Note 2), without a voluntary protection and conservation policy, in the medium term these high-quality ecosystems are in danger of disappearing. Yet we have many planning tools necessary for a good structuring of space and they are likely to reduce or even eliminate any risk of irreversible degradation (Note 3): In these island systems, whose degree of anthropization is variable in frequency and intensity from one area to another, it seems essential to take into account the small littoral floristic units which often host a multitude of species and phytocenoses, some of which are rare or endangered (Baillard, 2016; Imbert and Delbé, 2006, Bâ and Rivera-Ocasio, 2015, Imbert, et al., 2000). As an example and in a non-exhaustive way, this article proposes a synthesis of our current knowledge regarding Martinique's littoral vegetation under anthropic constraints (Figure 1). 


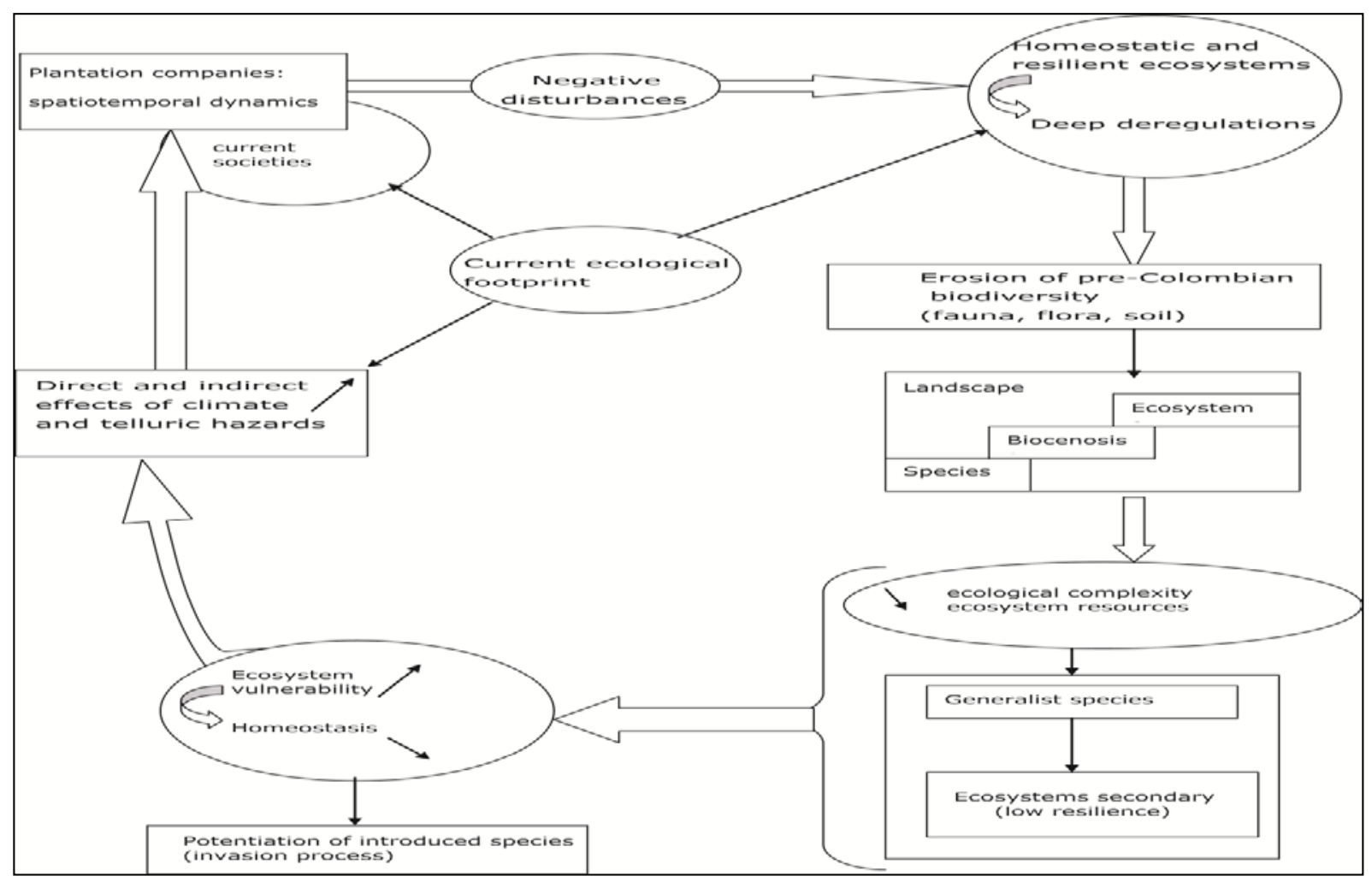

Figure 1. The effects of anthropization in Martinique

\section{General Method}

The old descriptions, the data of recent works and those of our predecessors cited below in the references, as well as recent field observations and inventories allowed us to describe the main structural and dynamic spatiotemporal characteristics of the littoral vegetation. In fact, in the types of vegetation influenced by specific bioclimates, the presence or absence as well as the dominance of species within phytocenoses were relevant spatial distribution descriptors, but also indicators of the structural and functional condition as well as the evolution stages.

\section{General Ecological Characteristics and Ecosystem Potential}

The coast of Martinique has varied and multiple forms resulting from the various tectonic events and erosion processes that followed each other over time. We can describe several facies and they generally belong to the following types (Note 4): Sandy beach, pebble beach, cliff, rocky margin, dry land vegetation, swamp forest, mangrove (Moore, Gilmer and Schill, 2014). Man (Note 5), the marine hydrodynamics and seasonal climatic disturbances (waves, depressions, storms and hurricanes) are the in main contemporary factors contributing to their evolution (Schleupner, 2007; Fricker and Forbes, 1988; Burke, et al., 2001). Human-induced erosion is alarming and adds to the natural erosion (Phillips and Jones, 2006): residences, businesses, industries, quarries, tourism, deforestation, agriculture, nautical and maritime infrastructures. The damage is high and results in a significant decline in littoral margins and associated biocenoses (Cushman, 1995; Ellison and Farnsworth, 1996; Flower and Imbert, 2006; Alongi, 2008).

The spatial limits of the coast of Martinique are difficult to identify and depend on the treated subject-matter. Nevertheless, they belong to the lower stage subjected to the dry sub-humid bioclimate (areas of the extreme south and north of the Caribbean) (Note 6) and the wet sub-humid bioclimate (Note 7) (South Atlantic and northern tip, Figures 2 and 3). Logically the rainfall distributions added to other physical factors determine the specific plant groups at any successional stage (Joseph, 2012). However, certain topographic configurations can result in specific mesological conditions close to those characteristics of the wet bioclimate. 


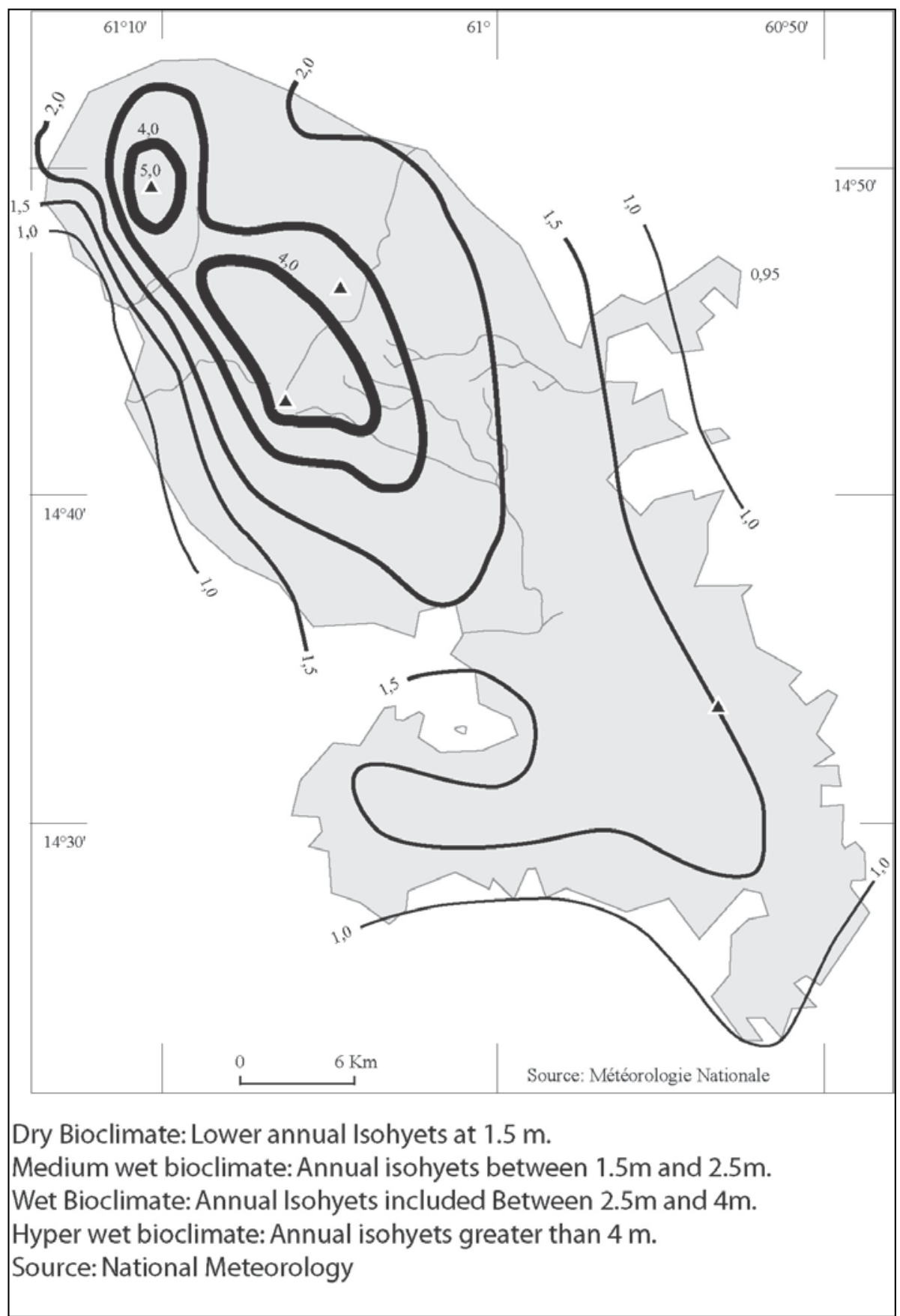

Figure 2. The different types of bioclimate in Martinique

Apart from the cliffs, rocky margins and inland areas where the often-discontinuous vegetation cover cannot surpass the shrub stage, the coastal vegetation has sylvatic potential (Joseph and Baillard, 2016). In the absence of any anthropization, the dry sub-humid and wet sub-humid bioclimates respectively condition the tropical seasonal evergreen forest of lower horizon and xeric facies and the typical tropical seasonal evergreen forest. In pre-Columbian times, these forests predominated and reached their supposedly climactic stage of maturity (Figure 2). On the windy ridges and in the valley bottoms, we also find floristic communities, few in number, distinctively similar to the semi-deciduous forest type in the tropical dry season (Note 8) and the tropical seasonal ombro-evergreen forest type (Note 9). 


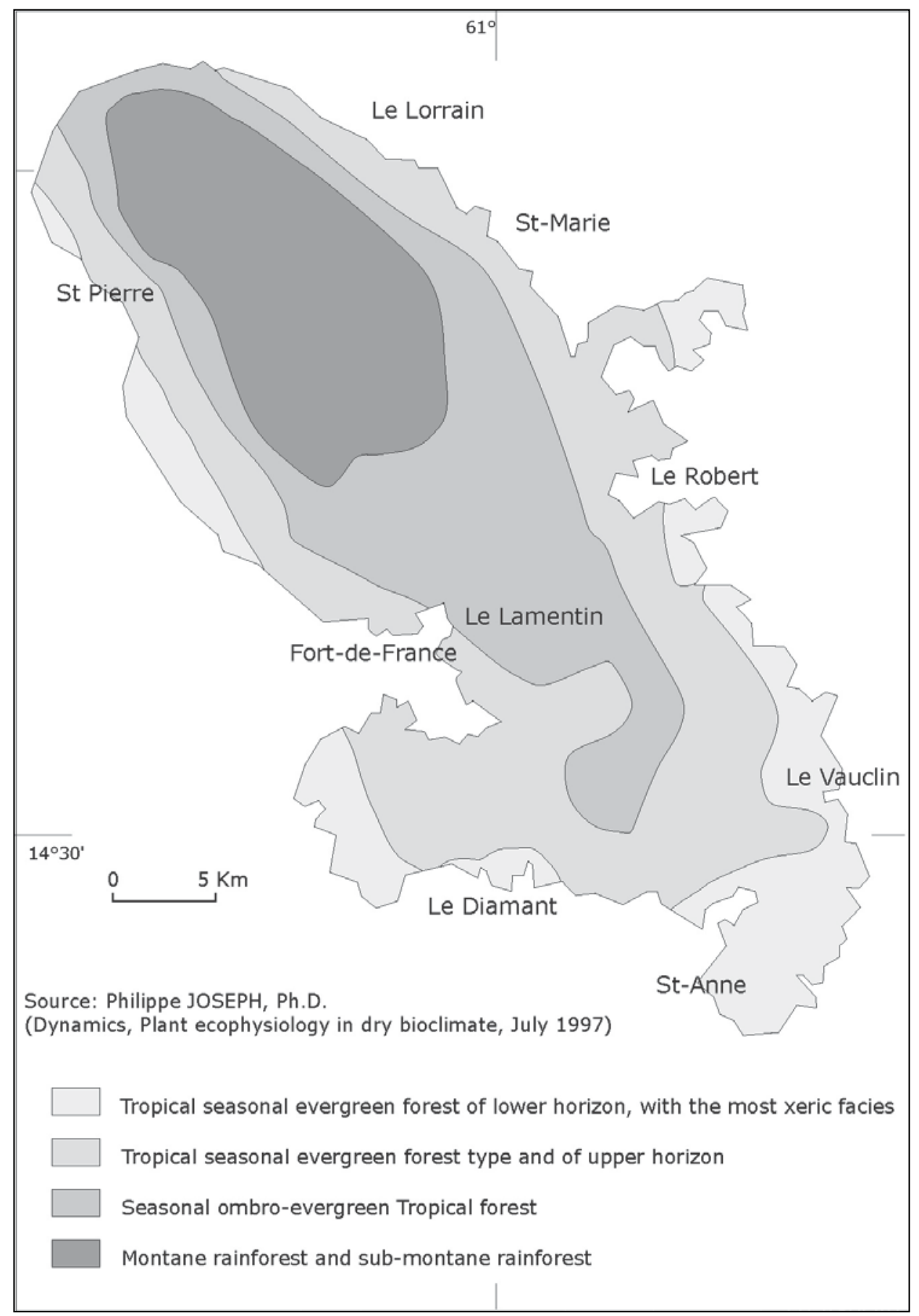

Figure 3. Martinique's vegetation cover in pre-Columbian times

In fact, these topographic facies modify the hydrological balance. On the ridges exposed to the wind, the evapotranspiration is much more important: Especially during a period of recession rainfall locally called "Lent". The permanent drying of the biotopes of the dry sub-humid bioclimate favours the lowland xeric species (Note 10). Conversely, due to the confinement which affects the duration of the sunshine and to the colluvium which results in deeper soils, on the valley bottoms the hygrometry and the water resources are relatively higher. These modalities allow the development of forest formations integrating, in varying proportions, sub-montane seasonal and sub-montane evergreen species (Joseph, Pagney and Tanasi, 2003). Although located on the lower floor, influenced by the dry bioclimate, they are classified in the class of tropical seasonal ombro-evergreen forests, which typically represent the interface or ecotone between the middle and upper floors(Note 11). 


\section{Evolution of Landscapes and Existing Ecological Diversity}

\subsection{The Main Features of Landscape Evolution}

Today's Martinican landscapes are the result of a long anthropic history. By 1635, in pre-Columbian times, the terrestrial ecosystems had reached a high level of complexity characterised by high biological diversity. The hunters, fishermen, gatherers and farmers of the time, the Amerindians, lived in almost perfect symbiosis with the different environments since their use of the vegetable and animal resources did not lead to significant modifications (Moreau, 1987). The activities of these first "tenants" of the island - for about 4000 years - were mainly intended for the survival of the populations (Brockway, 1979). In this case, a large number of elements of the plant world made up various formulations belonging to the food, dye, ritual and medicinal sectors [Tertre (Du), 1667, Moreau, 1987 \& Labat, 1972-1974]. Not to mention the trees used in the construction of furniture, houses and boats, including the Gommier Blanc (Dacryodes excelsa: Burseraceae) which is one of the most illustrious representatives.

From the outset of the occupation, the land clearing, selective harvesting of precious woods and the establishment of subsistence crops resulted in the collapse of the Pre-Columbian forest ecosystem in the lower zone (lower plant level: between 0 and 250 meters) and particularly in the coastal zone, (Delawarde, 1935, Fressinet, 1988, Acevedo-Rodríguez and Strong, 2008). Gradually, large cash crops such as sugarcane heavily participated in "insularising" the original forest cover. Around 1770 Martinique had become a vast agricultural territory from the littoral up to the lower limit of the middle floor: on average, circa 500 meters (Joseph, 1997, Thibault De Chanvalon, 1763). Apart from the sugar cane based households, the gardens of the small settlers who cleared the land were located on the impracticable slopes. From 1848, the upper third of the hills (Note 12), wood reserve for the residences and sanctuary of the remaining fauna, was occupied by the former slaves who had become agricultural workers. This corresponds to a further anthropogenic degradation of the forest ecosystem.

Finally, as elsewhere in the rest of the Caribbean basin, Martinique's existing vegetal carpet has been influenced by the successive societies. One of the major consequences is the loss of diversity in both species (animal and plant species), plant communities and ecosystems and landscapes (Hatzenberger, 1994). Progressively due to modernity, the abandonment of the wood resources as the sole domestic and industrial energy source has contributed to spontaneous reforestation, natural phenomena on the sloping areas and lands of low agricultural value. At present, many forest groups of varying sizes, no less rich both in terms of floristics and their complexity, are the result of the re-colonization process. In reality, Martinique's history is marked by specific modes of spatial organisation. The agriculture, the quasi-systematic use of timber and the establishment of human aggregates were the main anthropogenic factors (Note 13). The vegetal physiognomies of today's Martinique result from these unbalanced relations between men and their environments. By removing plant resources in the various island environments, the successive populations caused (Note 14) a surprisingly high but extremely vulnerable landscape diversity (Figure 4).

Unlike the Amerindian times when the forest was dominant and of high structuration (Bouton, 1640, Rochefort, 1667), at the beginning of this third millennium the coastal vegetation is assimilated to a dense mesh of shrubby, herbaceous, pre-forest and marginally forest units. Today's anthropic Martinique, like the other mountainous islands of the archipelago, possesses almost all the physiognomic and biocenic types of the inter-tropical plant mode. In fact, the anthropization has accentuated the natural mesological heterogeneity of the biotopes and resulted in the creation of a multitude of regressive or secondary floristic entities. The latter, derived from the pre-Columbian forests, correspond to various states of complexity and form a dense mosaic. Within the latter, biocenoses composed of highly specialized species specific to the optimal sylvatic phases and therefore of significant ecological interest, make it difficult to maintain their self-ecological and synecological durability (Figure 4). 


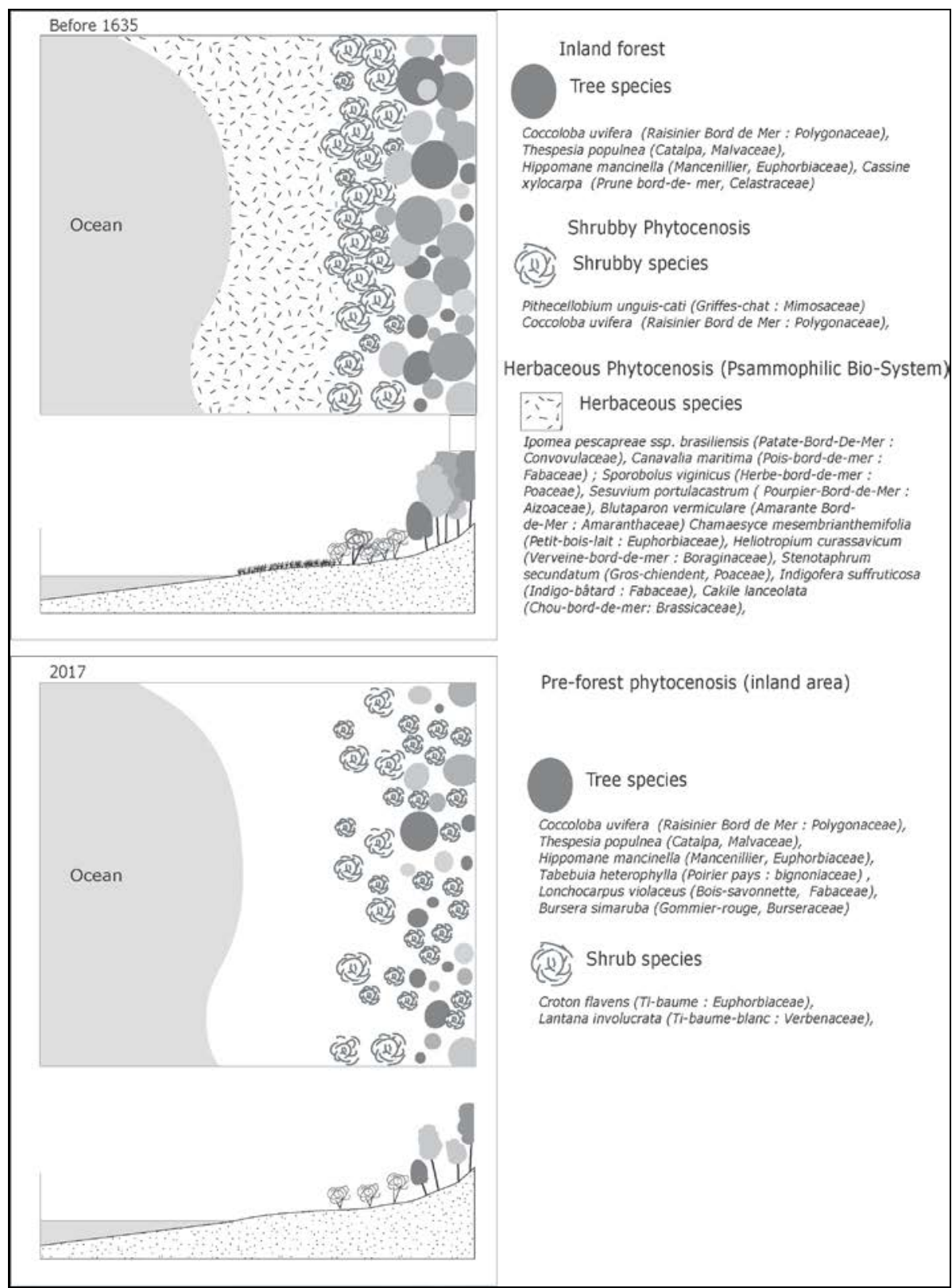

Figure 4. Evolution of the littoral vegetation

\subsection{Today's Ecosystemic and Biocenic Diversity: Coastal Vegetation}

In order of importance the physiognomies of the existing littoral vegetation are the shrub, herbaceous, mixed (shrub/herbaceous or shrub/tree), young pre-sylvatic and sylvatic ones (Moore, Gilmer and Schill, 2014). The structural secondary or late forests are very marginal. Apart from cliffs and rocky formations, most of which have retained their original appearance, the anthropized environments contain a plurality of evolution stages. From the marine surf to dry land, one passes from the sandy environment named psammophile, indicated by herbaceous phytocenoses, to regressive forest formations: shrubby communities materialize their interfaces. The floristic associations of these different biotopes are extremely diversified and generally form more or less parallel bands (Figure 4). Logically, within these bands, this diversity is the result of small factorial variations. Despite the lack of reliable data, in the light of field observations, we can state that at station scale the variations in micro-relief and climate result in demographic differences between species. In reality, the plurality of littoral domains corresponds to a plurality of installation sites associated with a collection of floristic species, also called species fund or floristic potential. The different floristic potentials contain many ecological profiles that form the basis of this observed community diversity. In general, the sandy, interface and dry land environments can be 
identified in a number of stations whose factorial characteristics give rise to specific predominant floristic processes. The natural mesological heterogeneity largely conditions most of the plant mosaic whose differences with the pre-colonial period are today accentuated by human activities.

\subsection{Sand or Psammophile Vegetation}

Only present on sandy beaches, the psammophile vegetation consists of scattered herbaceous associations. It is frequently limited to an "archipelago of monotypic floristic islands". Among the most common taxa which show the limits of the high water Ipomea pescapreae ssp. Brasiliensis (Patate-Bord-De-Mer, Convovulaceae); Canavalia maritima (Pois-bord-de-mer, Fabaceae); Sporobolus viginicus(Herbe-bord-de-mer, Poaceae). We can observe a few Sesuvium portulacastrum (Aizoaceae, Pourpier-Bord de Mer) and Blutaparon vermiculare (Amarante Bord de Mer, Amaranthaceae) individuals. Irrespective of their combinatory modes, within the various islets, these species develop root systems occupying large hypogeous volumes. Intertwined, anastomosed, the latter form dense networks resulting in an impenetrable carpet that mechanically protects the sandy sediments. The current "archipelagic" character of the psammophiles phytocenoses is the consequence of anthropization. Nevertheless, there are examples of beaches which possess a continuous vegetal cover like those of Martinique's prehistory. In general, these beaches are little frequented by the locals and have not yet been converted into tourist places. The continuous epigeal and root biomass resists the strong swells generated by the most violent hurricanes and fixes the sandy sediments in place (Figure 5, photos 1 \& 2, tables 1 \& 2). In 1999, Hurricane Lenny led to a sharp decline in sand beaches. Only the wooded inland area has been preserved, especially in the northern Caribbean and in some places in the peninsula of Sainte-Anne (commune of the extreme south). Like the beaches of the Amerindian era, Figure 5 shows the sandy systems of coral origin of two little islands locally called islets, one of which is stabilized (the Loup-Garou Islet) by a mainly grassy vegetation cover. These two examples give us an idea of the floristic organisation of the Lesser Antilles sandy systems. In general, most beaches used for water sports and adjacent to hotel complexes have suffered severe damage. In some cases, the erosion was so severe that, for a few months, it hindered the tourist activities. Even today, many beaches have not regained the level reached before 1999 (the LENNY hurricane).

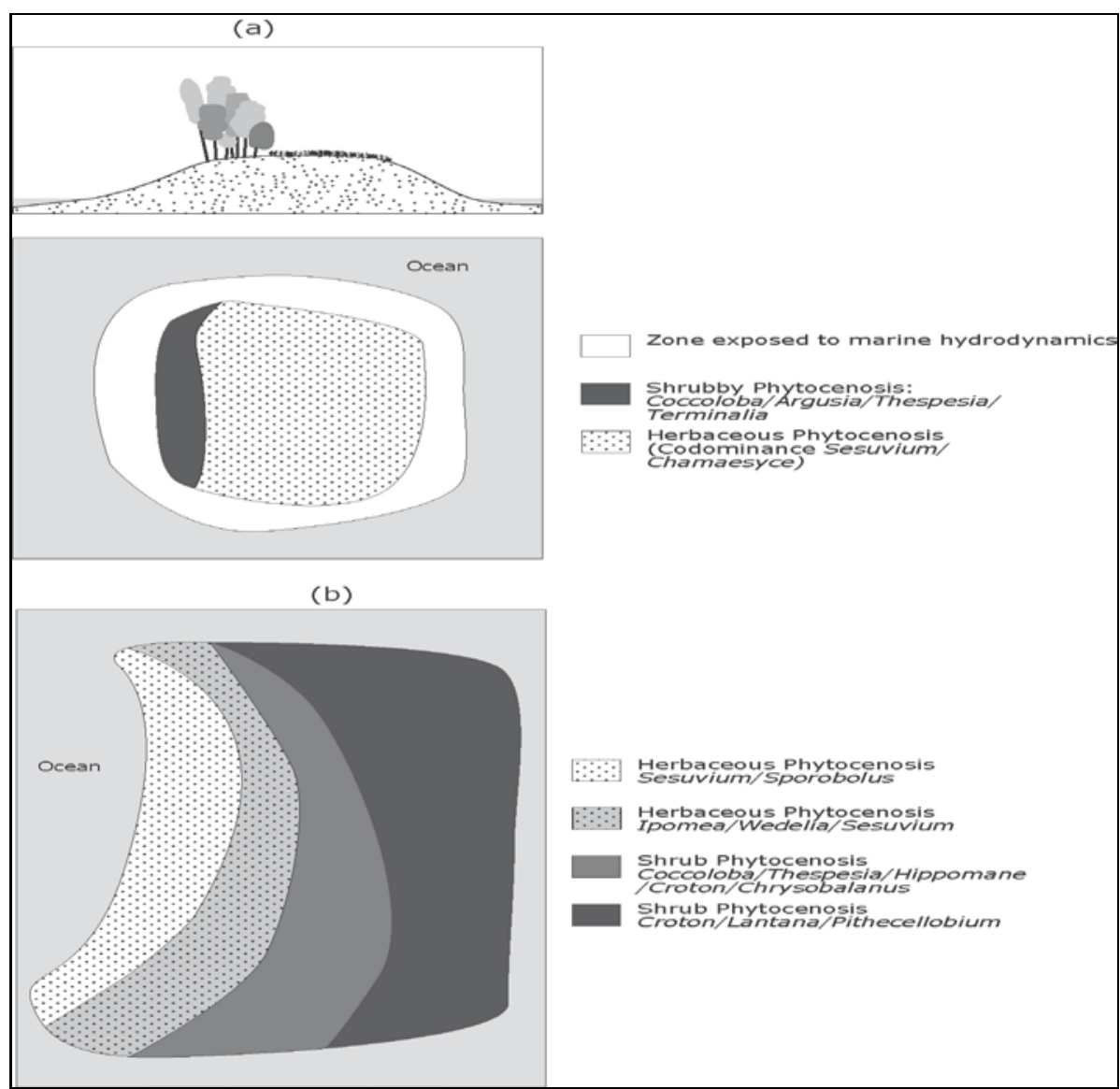

Figure 5. Schematic representation of the Loup-Garou (a) and Chevalier (b) islets 


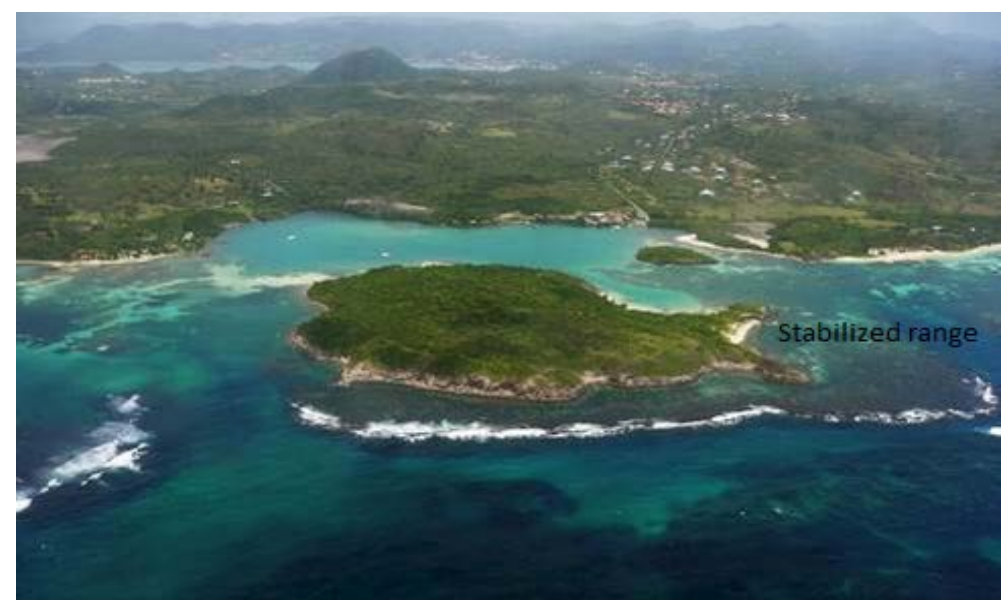

Photo 1. Geographical location of the Chevalier islet

Table 1. Key floristic species of the Chevalier islet (In red the psammophile species)

\begin{tabular}{|c|c|c|c|c|c|}
\hline Plant species & Families & Distribution & Temperament & Real physiognomic type & Potential physiognomic type \\
\hline Acacia macracantha & Mimosaceae & + & heliophyte & nanophaneraphyte i/m/s & nanophanerophyte s \\
\hline Acacia sp & Mimosaceae & + & heliophyte & nano/microphanerophyte i & microphanerophyte i \\
\hline Bontia daphnoides & Myoporaceae & + & heliophyte & nanophanerophyte i/m & microphanerophyte i \\
\hline Bursera simaruba & Burseraceae & + & heliophyte & microphanerophyte $\mathrm{i} / \mathrm{m}$ & mesophanerophyte m \\
\hline Capparis flexuosa & Capparidaceae & ++ & heliophyte & Liana & \\
\hline Capparis indica & Capparidaceae & + & heliophyte & nanophaneraphyte i & microphanerophyte i \\
\hline Cassitha filiformis & Lauraceae & + & heliophyte & Liana & \\
\hline Cissus verticillata & Vitaceae & $\mathrm{n}$ & heliophyte & Liana & \\
\hline Citharexylum spinosum & Verbenaceae & ++ & heliophyte & microphanerophyte i/m & mesophanerophyte i \\
\hline Clerodendrum aculeatum & Verbenaceae & ++ & heliophyte & nanophaneraphyte i/m & nanophaneraphytes \\
\hline Coccoloba uvifera & Polygonaceae & $\mathrm{n}$ & heliophyte & microphanerophyte m & mesophanerophyte i \\
\hline Cocos nucifera & Arecaceae & $\mathrm{n}$ & heliophyte & microphanerophyte $\mathrm{m} / \mathrm{s}$ & mesophanerophyte m \\
\hline Conocarpus erecta & Combretaceae & $\mathrm{n}$ & heliophyte & microphanerophyte m & mesophanerophyte i \\
\hline Cordia martinicensis & Boraginaceae & $\mathrm{n}$ & heliophyte & nanophaneraphyte i/m/s & microphanerophyte i \\
\hline Croton bixoides & Euphorbiaceae & ++++ & heliophyte & nanophaneraphyte i/m & nanophaneraphyte s \\
\hline Croton flavens & Euphorbiaceae & ++ & heliophyte & nanophaneraphyte $\mathrm{i} / \mathrm{m}$ & nanophaneraphytes \\
\hline Croton hircinus & Euphorbiaceae & $\mathrm{n}$ & heliophyte & nanophaneraphyte i & nanophaneraphytes \\
\hline Erithalis fruticosa & Rubiaceae & $\mathrm{n}$ & heliophyte & nanophaneraphyte $\mathrm{i} / \mathrm{m}$ & microphanerophyte i \\
\hline Erythroxylum havanense & Erythroxylaceae & ++ & heliophyte & nanophaneraphyte $\mathrm{i} / \mathrm{m}$ & nanophaneraphytes \\
\hline Ficus citrifolia & Moraceae & $\mathrm{n}$ & heliophyte & nanophaneraphyte $\mathrm{i} / \mathrm{m}$ & mégaphanerophyte \\
\hline Guettarda odotrata & Rubiaceae & $\mathrm{n}$ & heliophyte & nanophaneraphyte $\mathrm{i} / \mathrm{m}$ & microphanerophyte m \\
\hline Heletropium curassavic & Boraginaceae & $\mathrm{n}$ & heliophyte & Herbaceous & \\
\hline Hippomane mancinella & Euphorbiaceae & +++++ & heliophyte & nano/microphanerophyte i/m & mesophanerophyte m \\
\hline Ipomea pes-crapreae & Convolvulaceae & $\mathrm{n}$ & heliophyte & Herbaceous & \\
\hline Jacquinia armillaris & Theophrastaceae & $n$ & heliophyte ${ }^{2}$ & nanophaneraphyte i & nanophaneraphyte m \\
\hline Jatropha gossypiifolia & Euphorbiaceae & $\mathrm{n}$ & heliophyte & nanophaneraphyte i/m & nanophaneraphyte m \\
\hline Laetia thamnia & Flacourtiaceae & ++ & heliophyte & nanophaneraphyte i/m & nanophaneraphyte s \\
\hline Laguncularia racemosa & Combretaceae & $\mathrm{n}$ & heliophyte & microphanerophyte $\mathrm{m} / \mathrm{s}$ & mesophanerophyte i \\
\hline Lantana camara & Verbenaceae & $\mathrm{n}$ & heliophyte & nanophanerophyte i & nanophanerophyte m \\
\hline Lantana involucrata & Verbenaceae & $\mathrm{n}$ & heliophyte & nanophanerophyte i & nanophanerophyte m \\
\hline Malpighia emarginata? & Malpighiaceae & $\mathrm{n}$ & heliophyte & microphanerophyte i & microphanerophyte m \\
\hline Malpighia martinicensis? & Malpighiaceae & + & heliophyte & nanophaneraphyte i/m & microphanerophyte i \\
\hline Opuntia dillenii & Cactaceae & +++ & heliophyte & nanophaneraphyte i & nanophaneraphyte i \\
\hline Pilosocereus royeni & Cactaceae & +++ & heliophyte & nanophaneraphyte $\mathrm{i} / \mathrm{m} / \mathrm{s}$ & nanophaneraphytes \\
\hline Pisonia fragrans & Nyctaginaceae & ++++ & heliophyte ${ }^{2}$ & nano/microphanerophyte $\mathrm{i} / \mathrm{m}$ & mesophanerophytes \\
\hline Pisonia aculeata & Nyctaginaceae & $\mathrm{n}$ & heliophyte & Liana & \\
\hline Pithecellobium unguis-cati & i Mimosaceae & $\mathrm{n}$ & heliophyte & nanophanéraphyte m/s & microphanerophyte m \\
\hline
\end{tabular}




\begin{tabular}{llllll}
\hline Pluchea sp & Asteraceae & $\mathrm{n}$ & heliophyte & Herbaceous \\
Rauvolfia viridis & Apocynaceae & + & heliophyte & nanophaneraphyte i/m & microphanerophyte $\mathrm{m}$ \\
Rhizophora mangle & Rhizophoraceae & $\mathrm{n}$ & heliophyte & microphanerophyte i/m & mesophanerophyte $\mathrm{m}$ \\
Rivina humilis & Phytolaccaceae & $\mathrm{n}$ & heliophyte & Herbaceous \\
Senna bicapsularis & Caesalpiniaceae & $\mathrm{n}$ & heliophyte & nanophaneraphyte i/m & nanophaneraphyte m \\
Sesuvium portulacastrum & Aizoaceae & $\mathrm{n}$ & heliophyte & Herbaceous & \\
Solanum racemosum & Solanaceae & + & heliophyte & nanophaneraphyte i/m & nanophaneraphyte m \\
Sporobolus virginicus & Poaceae & $\mathrm{n}$ & heliophyte & Herbaceous & \\
Tabebuia heterophylla & Bignoniaceae & $\mathrm{n}$ & heliophyte & nanophaneraphyte i/m & mesophanerophyte s \\
Terminalia catapa & Combretaceae & $\mathrm{n}$ & heliophyte & microphanerophyte $\mathrm{m}$ & mesophanerophyte i \\
Thespesia populnea & Malvaceae & $\mathrm{n}$ & heliophyte & microphanerophyte i/m & microphanerophyte s \\
Tournefortia bicolor & Boraginaceae & + & heliophyte & Liana & \\
Tragia volubilis & Euphorbiaceae & +++ & heliophyte & Liana & \\
Wedelia trilobata & Asteraceae & $\mathrm{n}$ & heliophyte & Herbaceous & \\
& Malvaceae & + & heliophyte & Herbaceous & \\
& Cyperaces & $\mathrm{n}$ & heliophyte & Herbaceous & \\
\hline
\end{tabular}

Nanophaneraphyte : Height between 0 and 2 meters-/microphanerophyte: Height between 2 and 8 meters/

i : inferior-m: medium - s: superior/

$(+)$ :Importance of the descriptor $-\mathrm{n}$ : negligible

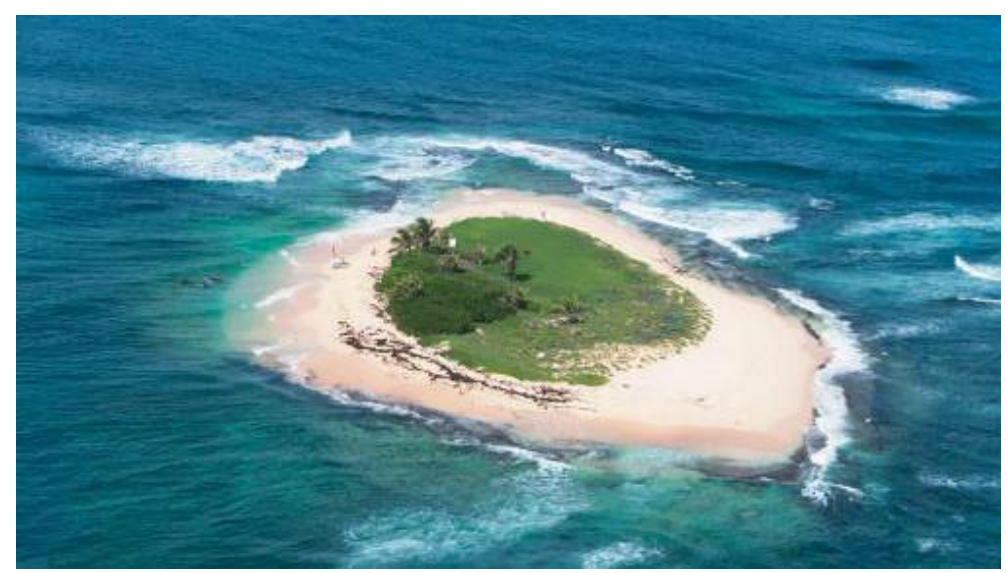

Photo 2. Geographic location of the Loup-Garou islet

Table 2. The main floristic species of the Loup-Garou islet

\begin{tabular}{lccccc}
\hline Plant species & Families & Distribution & Temperament & Real physiognomic type Potential physiognomic type \\
\hline Sesuvium portulacastrum & Aizoaceae & +++++ & heliophyte & Herbaceous & \\
Chamaesyce mesembrianthemifolia & Euphorbiaceae & +++++ & heliophyte & Nanophanerophyte & Nanophanerophyte.I \\
Suriana maritima & Surianaceae & + & heliophyte & Nanophanerophyte & Nanophanerophyte.I \\
Coccoloba uvifera & Polygonaceae & ++ & heliophyte & Microphanerophyte & Microphanerophyte.I \\
Argusia gnaphalodes? & Boraginaceae & ++ & heliophyte & Microphanerophyte. & Nanophanerophyte.s \\
Thespesia populnea & Malvaceae & + & heliophyte & Microphanerophyte & Nanophanerophyte s \\
Cocos nucifera & Arecacea & $\mathrm{n}$ & heliophyte & Mesophanerophyte & Nanophanerophyte s \\
Terminalia catappa & Combretaceae & $\mathrm{n}$ & heliophyte & Mesophanerophyte & Nanophanerophyte s \\
\hline
\end{tabular}

Nanophaneraphyte : Height between 0 and 2 meters-/microphanerophyte: Height between 2 and 8 meter

\subsection{Maritime Mangroves}

Mangroves are the main wetland environments on the coast of Martinique. They exhibit differences in structure and architecture as well as in the observed spatial series. We record: alluvial marine mangroves, colluvial marine mangroves and swamp or brackish water mangroves. In their protected bays or coves, the alluvial and colluvial 
mangroves are related to terrigenous sediments contributed by rivers and to the erosion resulting from slope deforestation (Figure 6). The Bay of Fort-de-France mangrove forest, fed by several important rivers, is the most extensive and presents spatial series, which depend on the topographical features of the coastal areas (Figure 6). The complexity of this alluvial mangrove are not rooted in its specific diversity which is in fact weak, but in the different arrangement of the pioneer species (exposed to the oceanic dynamic) compared to dry land.

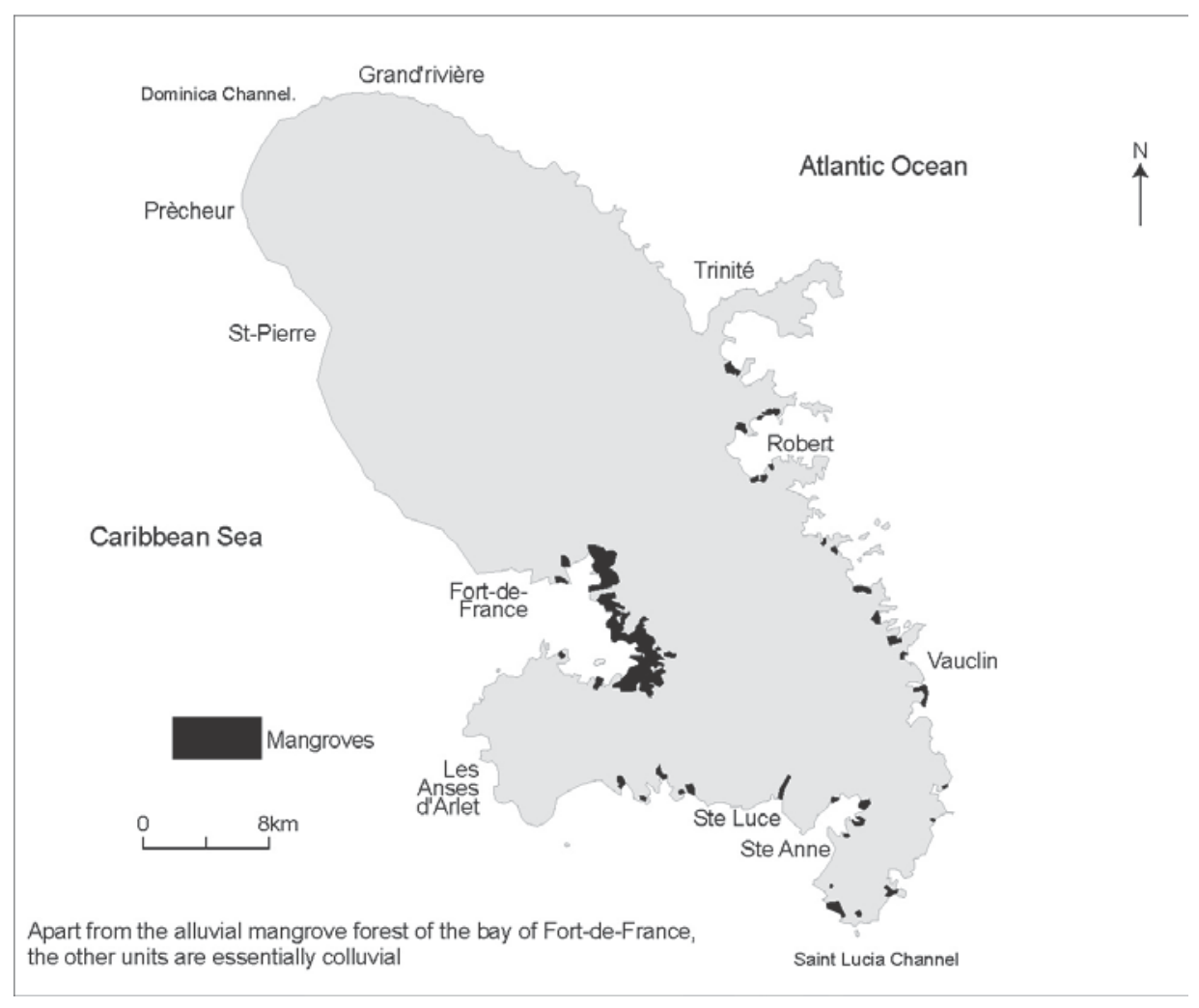

Figure 6. Location of Martinique’s mangroves

In general, four tree species form the floristic potential of this wet forest. The pioneer front, permanently flooded, is a mono-specific Rhizophora mangle (Rhizophoraceae) formation. Alternatively flooded during the rainy season and exposed during the rainfall deficit period, the mangrove inland area is generally composed, in ratios of varying dominance and according to precise spatial series, of Conocarpus erectus (Combretaceae), Avicennia germinans (Avicenniaceae) and Laguncularia racemosa (Combretaceae). The golden fern (Acrostichum aureum: Pteridophytes) colonizes the large natural and anthropogenic gaps. In a certain way, it indicates the regressive or secondary phase of this forest type. The hygrophilous grasslands dominated by the herbaceous species, particularly of the Cyperaceae family, indicate a deep degradation. Figures 8 to 13 show variations in diameters and heights of tree species populations between the quadrats of transects 1 and 2 (Figure 7). These variations also apply between these two transects. The analysis of Figures 10 and 13 shows profound differences in the spatial distribution of species populations. In transect 1, Rhizophora mangle, Avicennia germinans and Laguncularia racemosa are present in a large number of quadrats with notable variations in the number of individuals (Figure 10). Concerning transect 2, the spatial series for the same species differs strongly and seems conform to the classic spatial series of tree species of the Lesser Antilles alluvial mangrove: and this, despite the fact that Conocarpus erectus has not been recorded (Figure 13). However, overall, Rhizophora mangle and Avicennia germinans have denser populations. The presence of Rhizophora mangle in almost all quadrats of transect 1 (Figure 10), the presence of Laguncularia racemosa within the Rhizophora mangle formations in the maritime area in transect 2 and the absence of Conocarpus erectus (Figure 13) lead to questions that cannot be answered in the light of the existing data. 


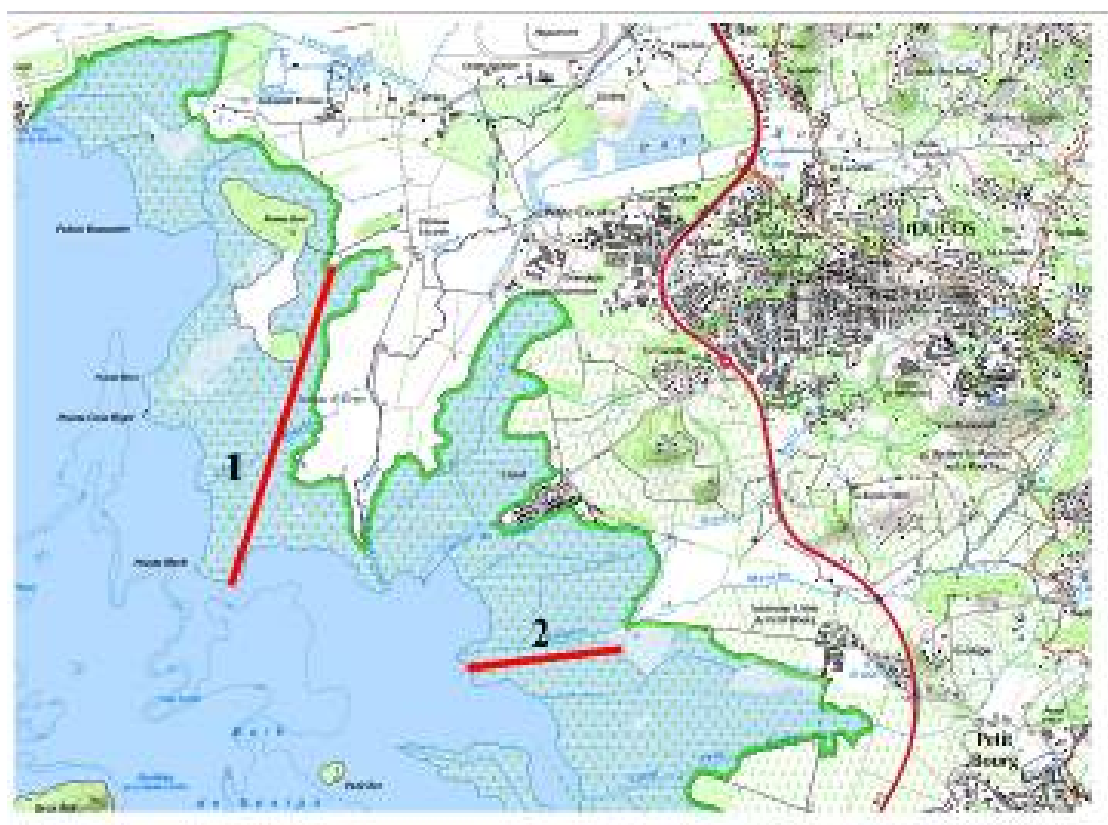

Figure 7. Transects in the Fort-de-France Bay Mangrove

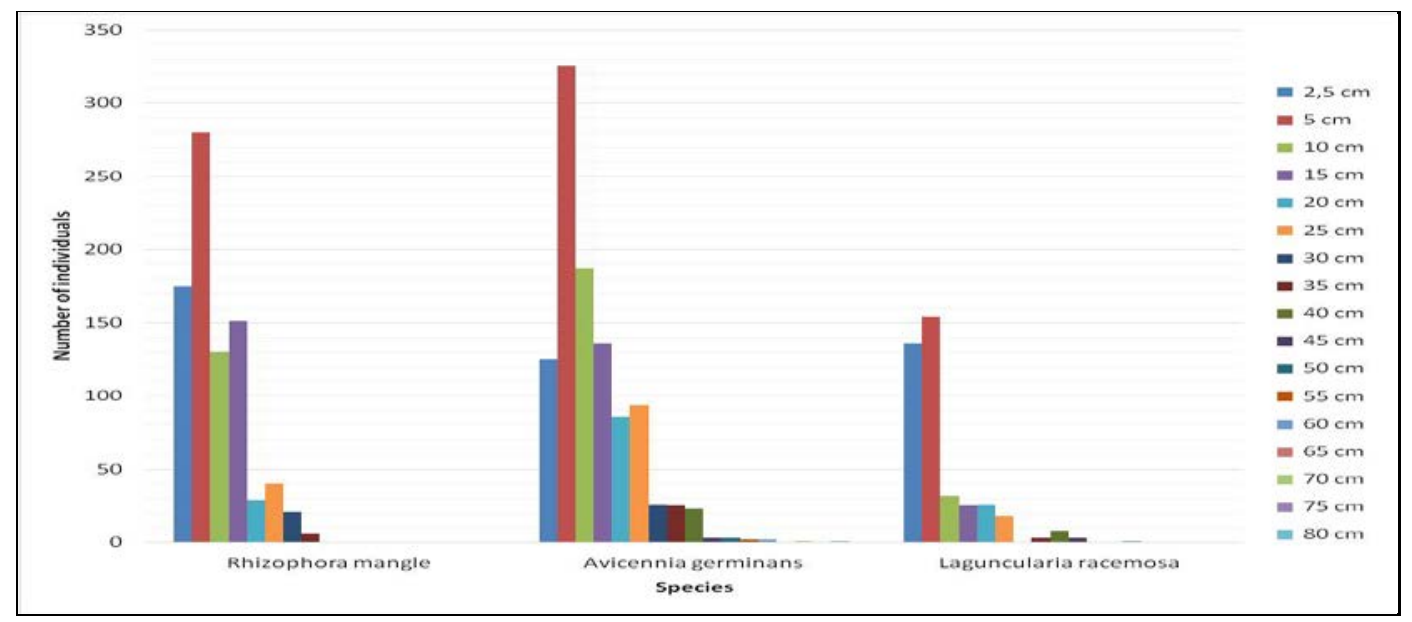

Figure 8. Distribution of the diameters of species populations [transect No. 1, Figure 7]

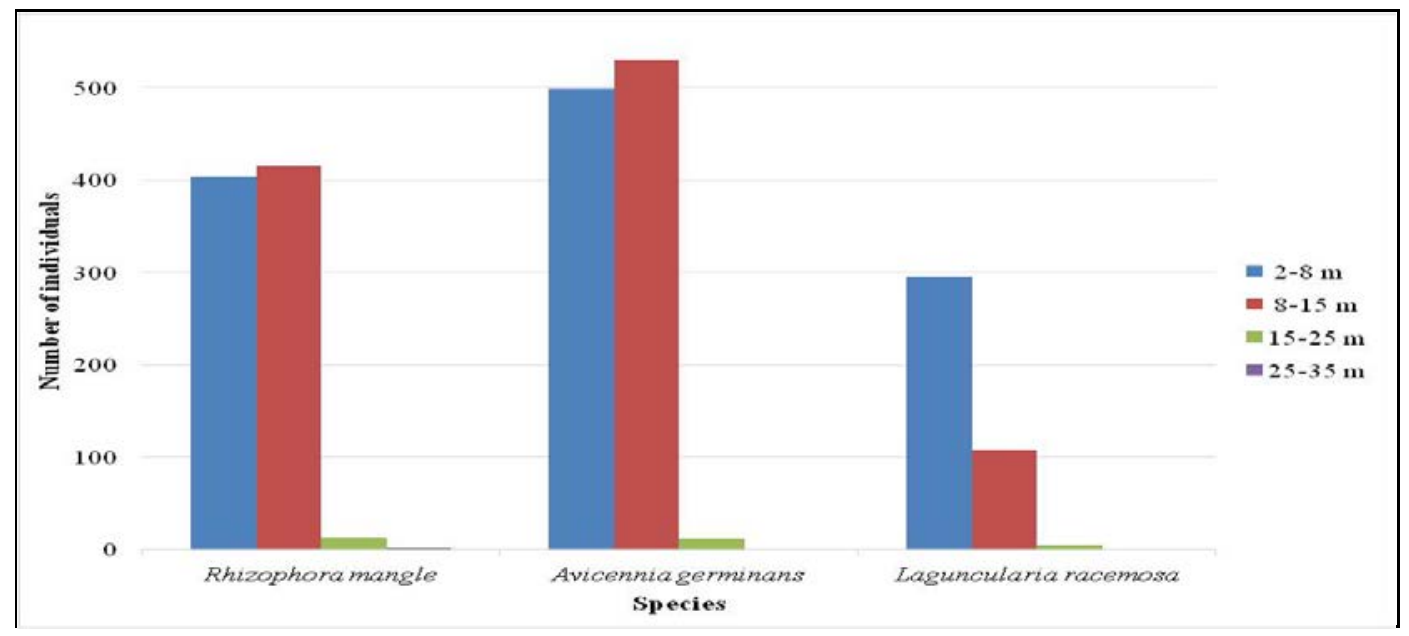

Figure 9. Distribution of heights of species populations (transect No. 1, Figure 7) 


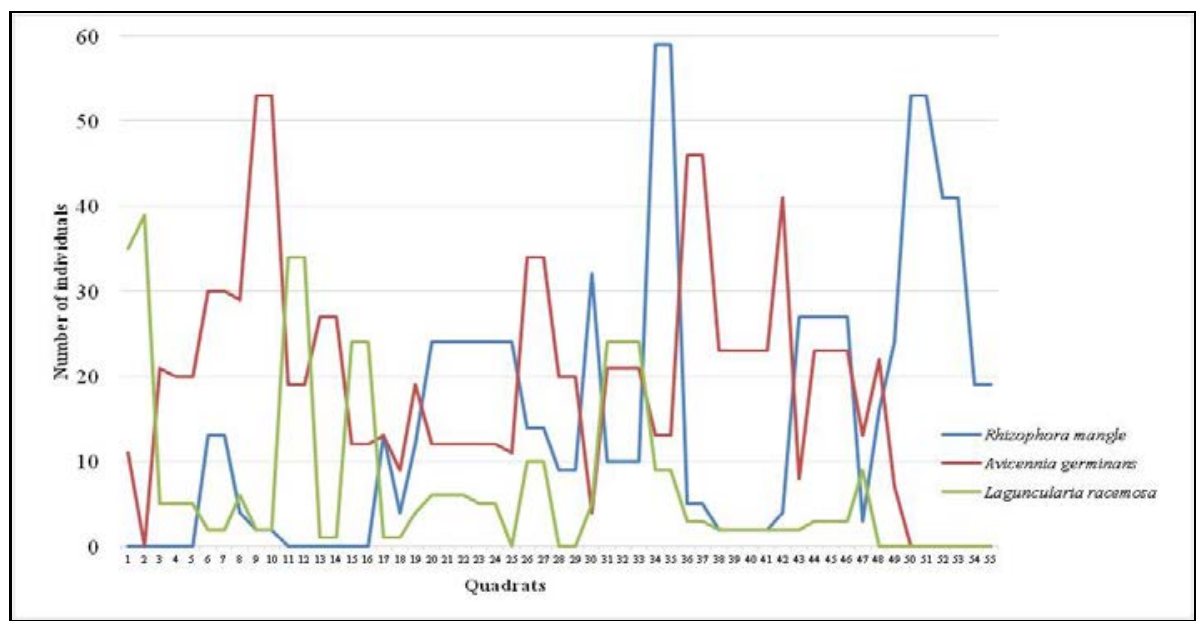

Figure 10. Quantitative distribution of species from dry land (1) to sea (25)

Ecosystemically inconsistent with the definition of mangrove, the "colluvial mangrove" occupies most of the coves and small bays of the southern coastal fringes of the Atlantic and the Caribbean Sea (Figures 6). Many originate from anthropogenic sources, they are limited to a mono-specific Rhizophora mangle formation which borders a sort of very marginal inland area. In the latter, in very low densities, we can see the isolated or gregarious species of the alluvial mangrove. Nevertheless, the presence of Avicennia schaueriana (Avicenniaceae), a rare species with generally very low populations, is one of the main characteristics of this type of mangrove (the colluvial mangrove).

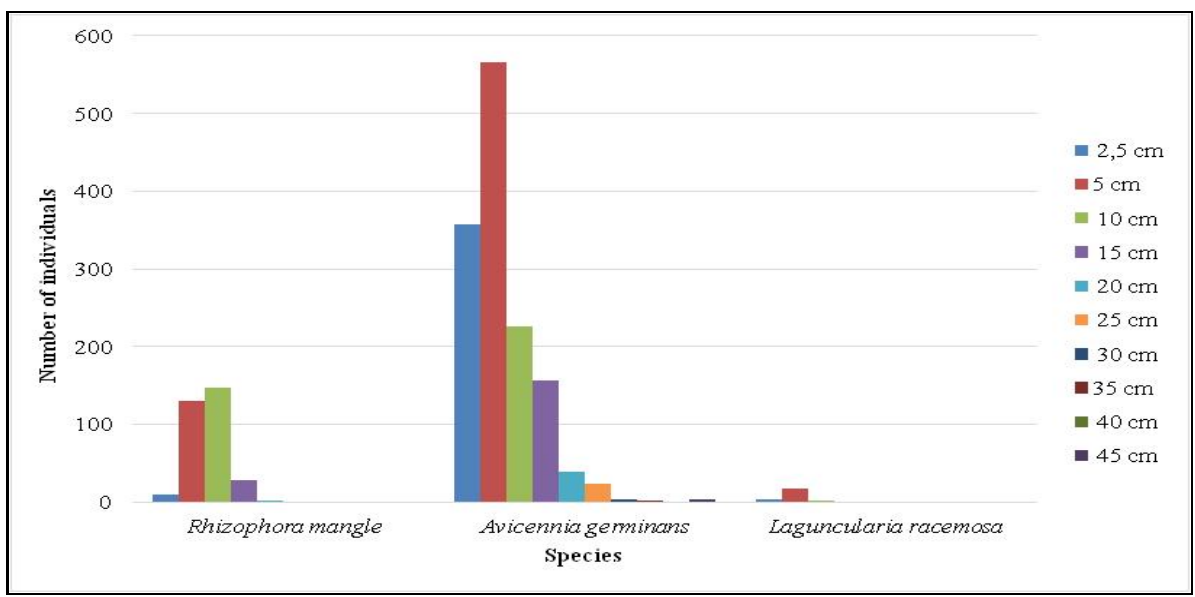

Figure 11. Distribution of diameters (transect No. 2, Figure 7)

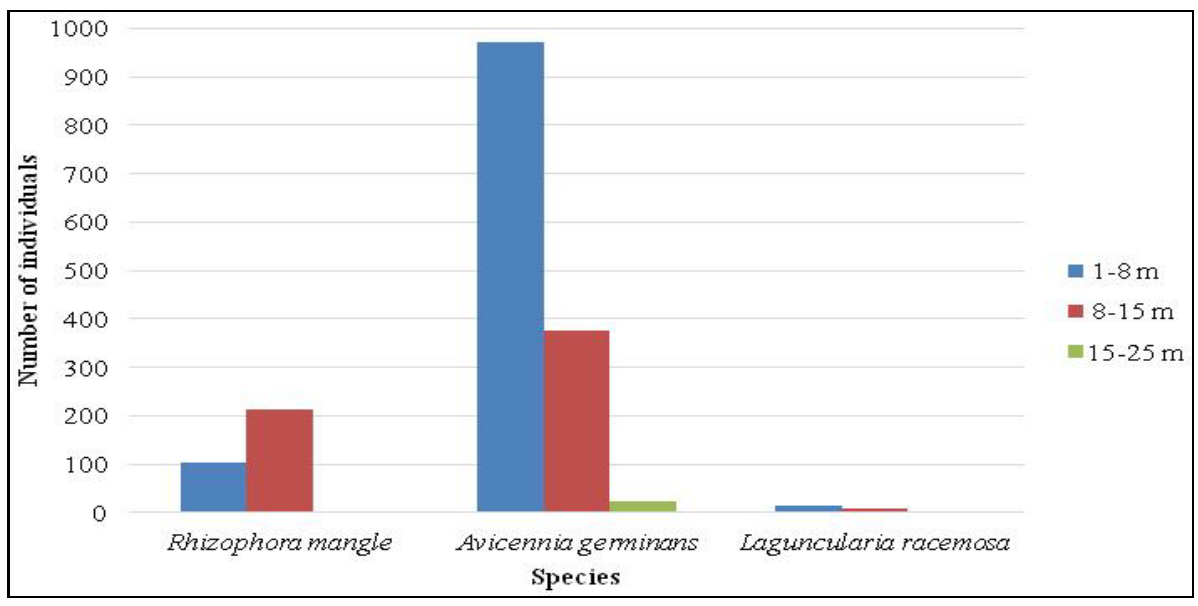

Figure 12. Height Distribution (Transect No. 2, Figure 7) 


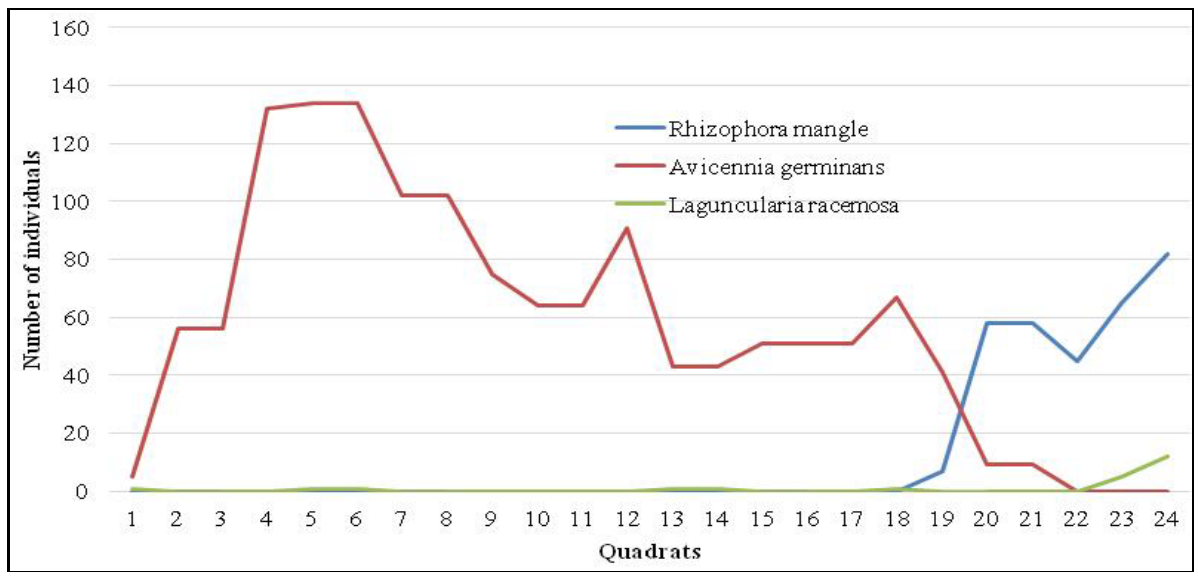

Figure 13. Quantitative distribution of species from dry land (1) to sea (24)

\subsection{The Swamp Mangrove (Galion-Commune of Trinite, Figure 14)}

To these two types of mangroves we add the one naturally located in the prolongation of the inland mangrove area and which is flooded in the rainy season and emerged in the dry season: the palustrine mangrove. This marshy forest is very undeveloped in Martinique unlike Guadeloupe and Dominica. The last unit that escaped the various phases of anthropization is on a littoral portion of the commune of Trinite (Figure 14, Photo 3). Boxed between sugarcane fields, residences, commercial and road infrastructures, this relict wet forest, essentially composed of Pterocarpus officinalis (Note 15) (Mangle medaille, Fabaceae) is very vulnerable. In Figure 15, the individuals' diameters, heights and first ramification heights show variations among them and within the quadrats. This fact must be related to the demographic structure of the Pterocarpus officinalis characterised by various stages of morphogenetic development.

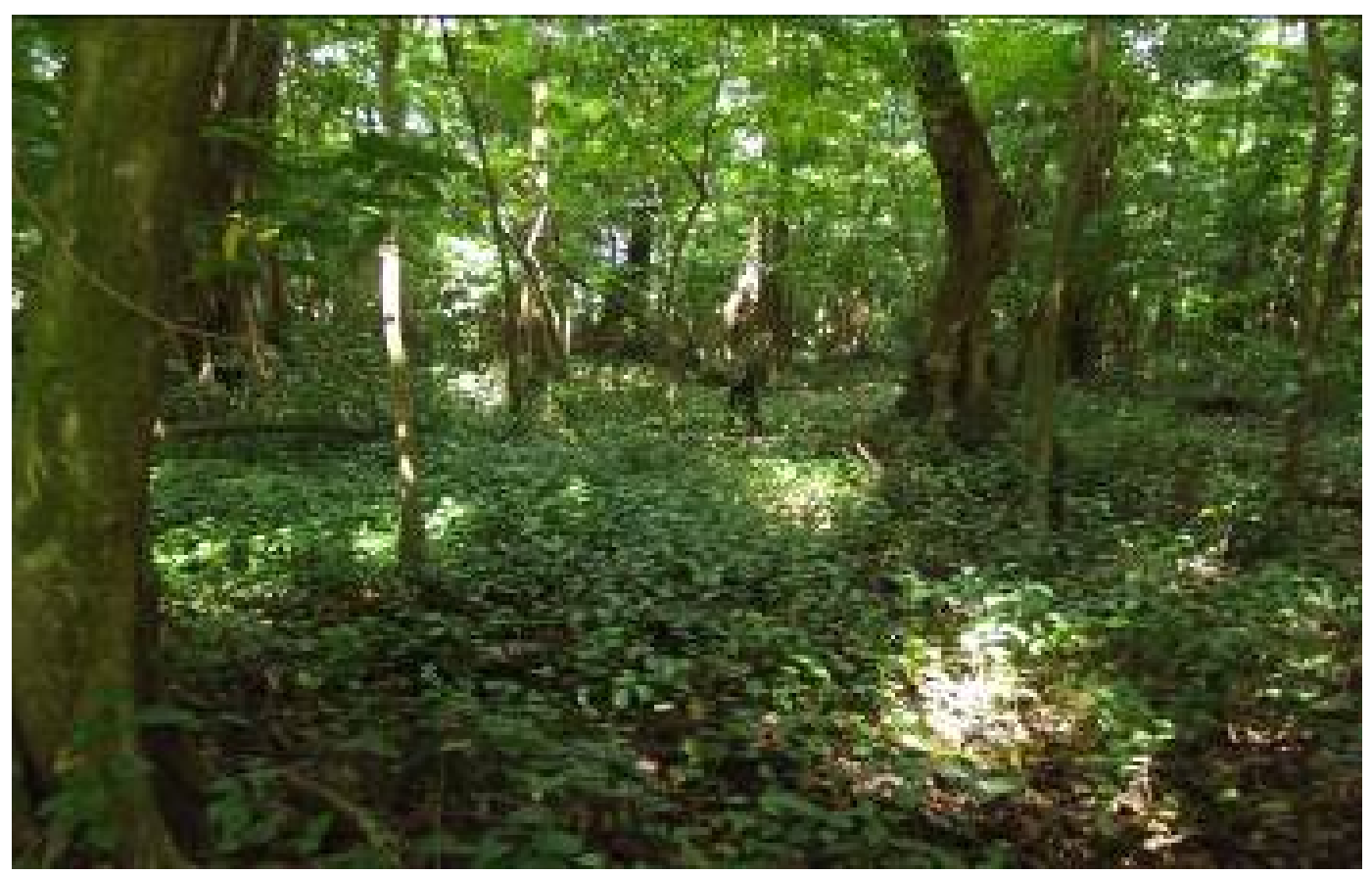

Photo 3. Landscape of the Swamp Mangrove 


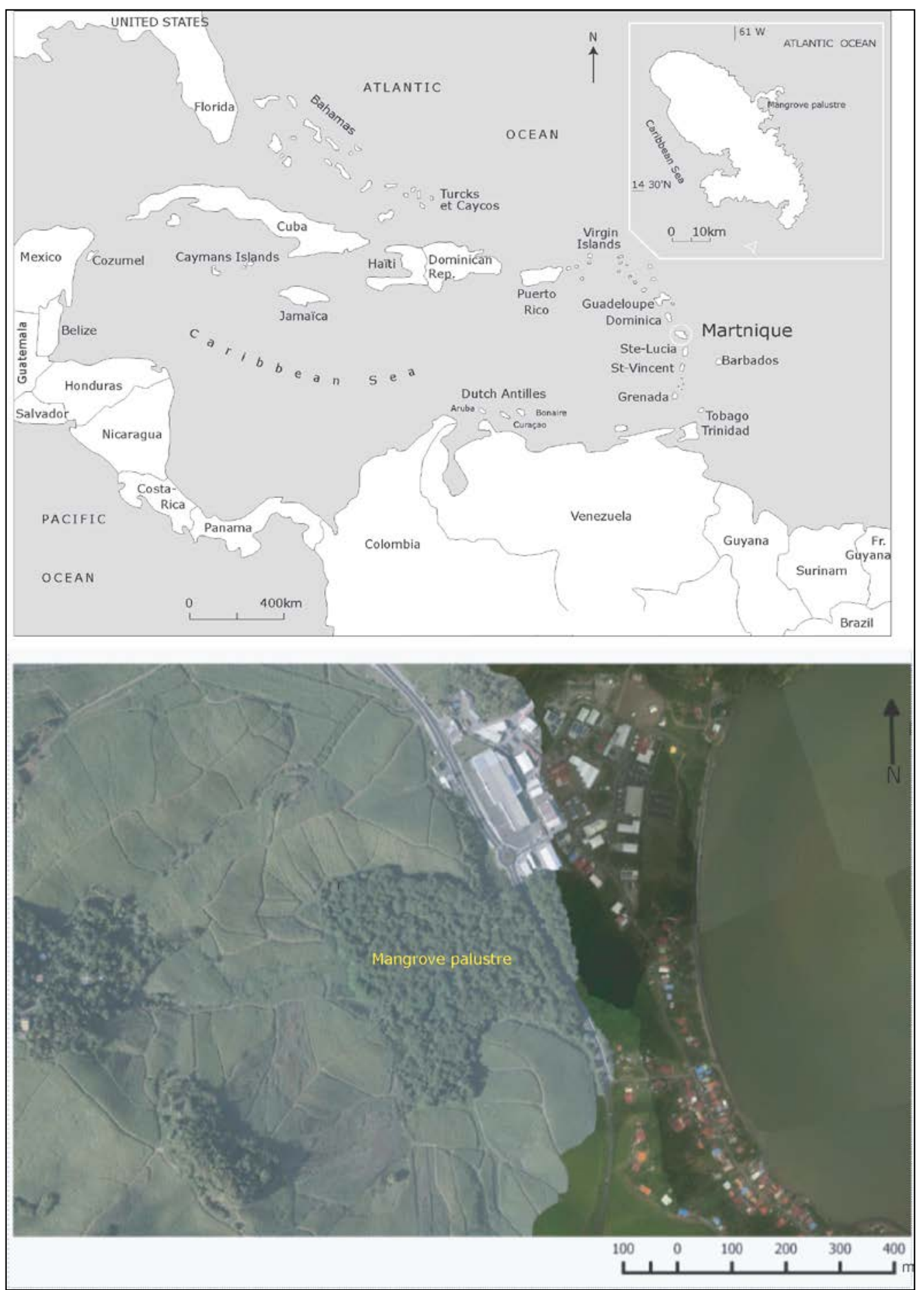

Figure 14. Location of the Mangrove du Galion

The road linking the Robert commune and that of Trinité subdivides this phytocenosis, rare and endangered in Martinique, in two units which communicate little from a hydrological point of view (Figure 14). In fact, the unit that adjoins the sugar cane fields is less flooded during the rainy period locally known as wintering (Note 16). The forest edge effect, which led to ecological changes characterised by the development of a regressive flora on dry land, is one of the significant consequences of road construction. 


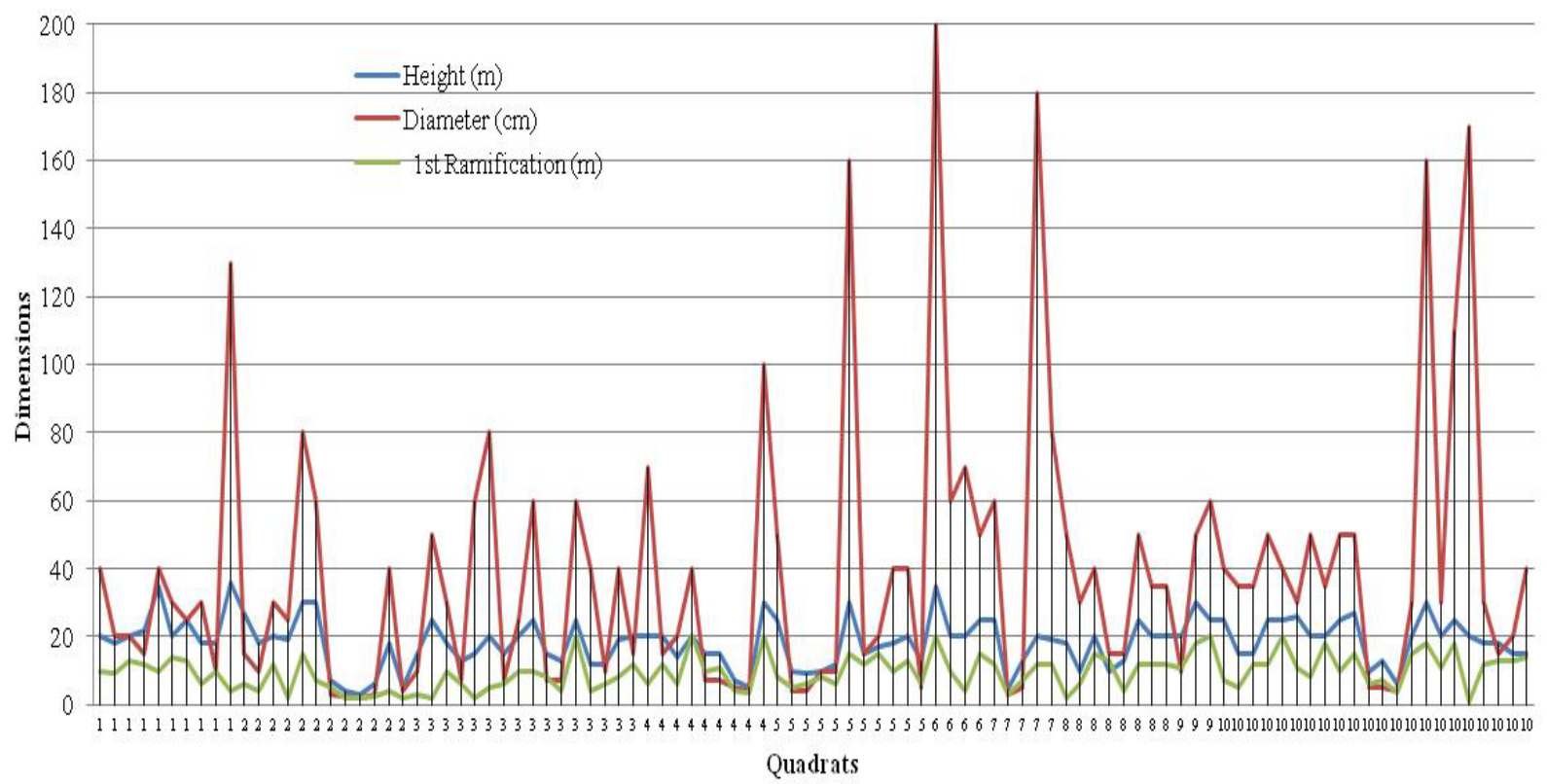

Figure 15. Example of distribution of diameters, heights and first ramifications

\subsection{Rocks, Cliffs, Edges and Rocky Cornices}

Rocks, cliffs, rocky edges and rocky cornices are among the most specific coastal facets from a floristic point of view. In fact, the vegetation is discontinuous and sometimes non-existent. The phytocenoses are similar to those of the early waves of plant dynamics in some dry land environments (pioneer successions, Reinhold-Castro et al., 2013, Li et al., 2014). Most of them are herbaceous, shrubs and heliophilous shrubs of the Piperaceae family (genera Piper and Peperomia), Euphorbiaceae, Orchidaceae, Aracées, Bromeliaceae, Cactaceae, Agavaceae, Flacourtiaceae, and Poaceae; Bignoniaceae, Nyctaginaceae, Boraginaceae, Verbaceaceae, Mimosaceae, Erythroxylaceae, Rubiaceae and Myrtaceae.

Depending on the bioclimate, the species can be hygrophilic, mesophilic or xerophilic. The trees are very poorly represented and those which grow there branch very low and often have shrub characteristics. The difficult environmental conditions are responsible for this phenomenon, in particular the high slope and skeletal soils in often windy areas subjected to the dry bioclimate. The rocky areas with centimetric and metric elements can only allow the development of plants in particular sites called "accumulation zones". They consequently condition the density of stems and result in a very heterogeneous distribution of taxon populations. As for the cliffs, the edges and the cornices, the vegetation (Note 17) is reduced to isolated individuals or tufts ensuring their biological cycles in the anfractuosities of the environments that are accumulation zones as well, just like those in rocky areas. Again, irrespective of their bioclimatic affiliation, the species are heliophilous. These generalist plants grow mainly in degraded environments with a poorly evolved edaphic system. On the windy slopes, trees often present crown asymmetry. To reduce evapotranspiration, they reduce the part of the crowns exposed to the wind: this is the phenomenon of anamorphosis or adaptive deformation of plants subjected to extreme ecological conditions. Compared to dry land biotopes, the floristic diversity is much lower.

\subsection{The Dry Land Biotopes}

With forest potential, the dry land environments influenced by dry sub-humid and sub-humid wet bioclimates have a relatively mild relief. The floristic units are diversified both from the specific, architectural, structural as well as physiognomic point of view and belong to the different phases of the extra and intra-sylvatic successional cycles. The enclosed valleys, which are often the minor bed of small, intermittent watercourses, may allow the installation of wetter plant communities just like those located higher in elevation (Note 18). For example, some watercourses (gullies or rivers) of the dry coastline condition the establishment of typical seasonal evergreen forest groups whereas the macroclimate should only allow the development of evergreen seasonal forests of lower horizon and xeric facies. Conversely, the coastal strips subjected to the wet sub-humid bioclimate may harbour sub-montane rainforest formations normally conditioned by the wet bioclimate. These specific cases are examples of vegetation inversion due both to their confined nature and the presence of perennial or seasonal streams as well as the wind's action. 


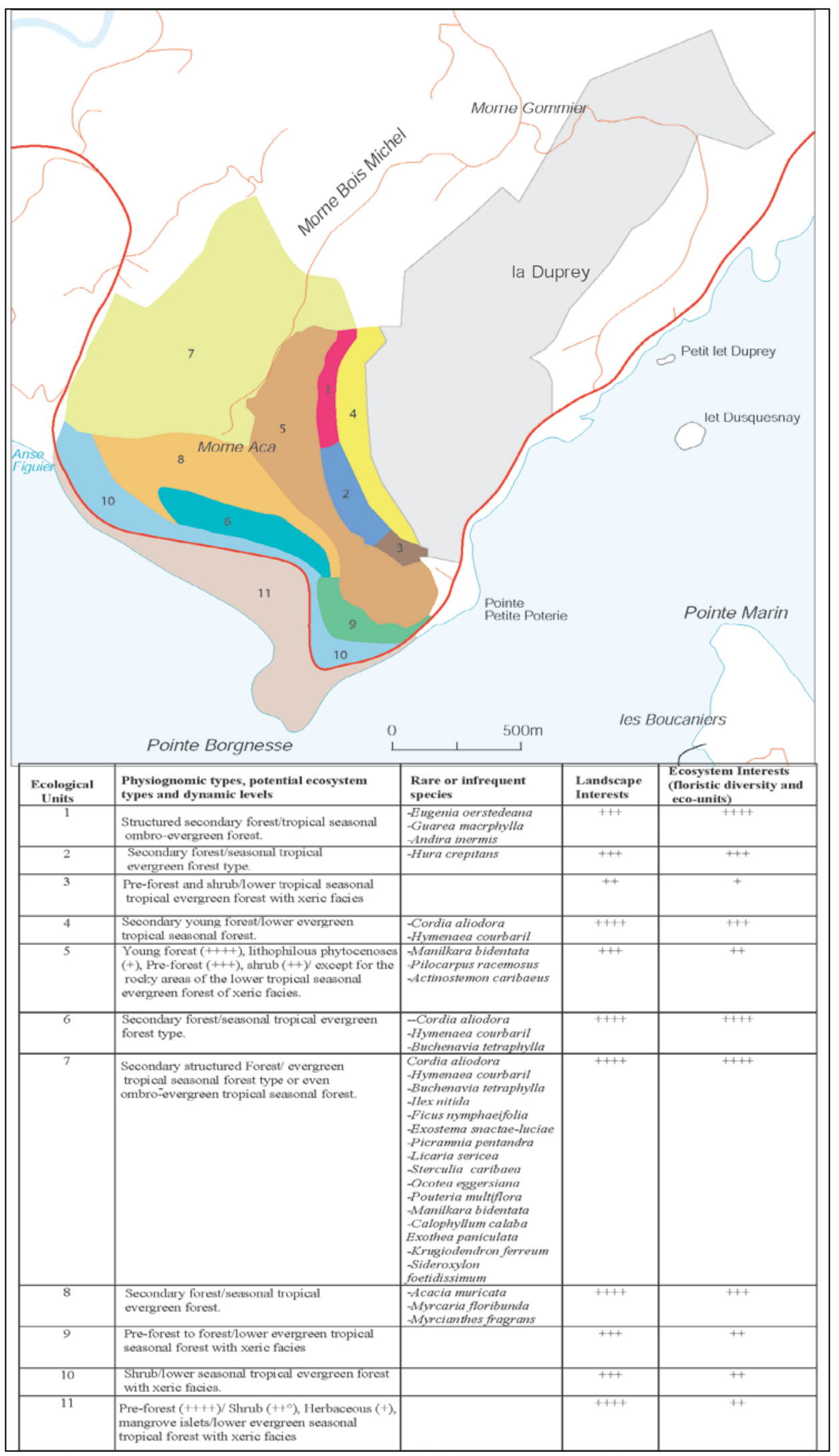

Figure 16. Ecosystemic, floristic and landscape characteristics of Pointe Borgnesse and Morne 
In order of preponderance, we find the dynamic fruit, shrubby, pre-forest, secondary forest stages. The few advanced formations are late secondary forests. The existing floristic combinations are regressive and result from the various anthropic phases occurred since 1635 which accentuated the mesological variability. These are all facets of biodiversity. Nevertheless, the forest ecosystems are the richest, both at specific and community level. They have a primary ecological and economic role. In fact, the coastal forests, especially those that are mature, permanently protect the edaphic systems of the inland areas and the sloping hillsides from the cyclonic swells. In 1999, the high-energy swell of hurricane LENNY completely removed the sandy beaches, while the inland areas colonized by forest vegetation were little or not at all eroded. Figure 16 gives us an idea of the spatiotemporal organisation of coastal phytocenoses in the southern part of Martinique (Le morne ACA).

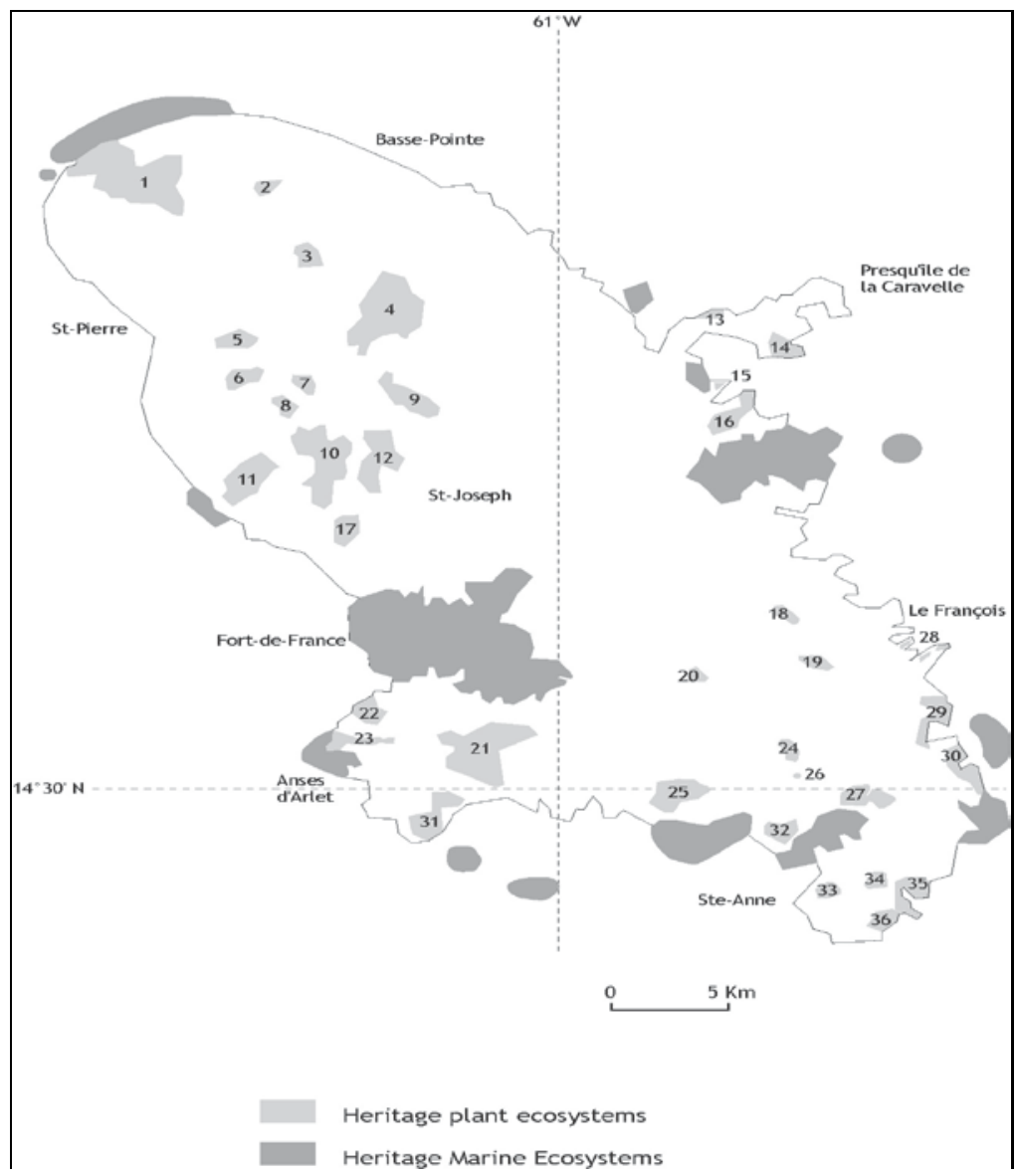

Figure 17. The natural plant and marine monuments of Martinique (Annex 1)

\section{The Role of Littoral Vegetation in Future Development (Some General Information)}

The flora of the Martinican coastline is diversified at all levels of biological complexity, from species to landscape, through ecosystem and phytocenoses (Note 19). The constitutive units represent as many evolutionary trajectories resulting from an anthropization which is unequal in frequency and intensity in both time and space (Note 20). Like a photographic film, the plant ecosystem of the littoral of this island, like all humanized plant ecosystems in the world, recorded the relationships of successive societies with their floristic environments. As a consequence, this dense mosaic, in which physiognomies, species and plant groups belonging to different dynamic stages intertwine and co-exist, has a heritage nature. The forests, in particular, are often natural monuments which can be used and serve as a context for controlled management [Figure 17 and Annex 1 (coastal natural monuments are in red)]. In general, the forests as well as the other aspects of the plant environment represent essential landscape elements. They are representative of a certain insular "tropicality" (Note 21) which forms the basis of the tourist attraction and a multiplicity of activities linked to the well-being provided by the marine (diving, bathing, etc.) and terrestrial (camping, hiking, etc.) biotopes.

For the future development of Martinique, these natural monuments must become structuring elements which will serve as axes of urbanity in the cities and rural axes in rural areas. Logically all the uses must be specific and 
reach a minimal balance between Nature and Society. In this context, the ecological tourism will represent one of the main engines of development. It will rely on the flora's exceptional character. This refers to its taxonomic diversity and its biocenic, architectural and structural complexity. Today's forest coasts are biological conservatories of small spatial dimensions which are subjected to multiple anthropic pressures (hunting activities, selective harvesting, residences, agriculture, road infrastructures, networks, etc.). Since these biotopes are not redundant, in view of their expressed pluralistic richness, we must implement management strategies that can sustain them while using them at the same time.

Irrespective of the area in question, the growth of the consumption economy leads to sectoral planning that consumes space. Plots of land are regularly taken out of the natural environments, particularly forested ones and converted into tourist and commercial complexes, or in collective and individual residences (Note 22). To this dramatic situation we add the steady increase in road size and the proliferation of roundabouts symptomatic of an archaic and inefficient transport system. This situation strongly encourages the acquisition of individual vehicles and the recurrent traffic jams almost at any hour of the day are the direct effects of this "societal pathology".

This waste of space on a small island and the lack of land reserves prompted the municipalities to revise their Local Plans of Urban Planning (PLU) formerly known as Land Use Plans (POS). Despite numerous national laws and guidelines on landscape, coastal balance and biodiversity, it is extremely difficult to combine the economic development with the protection of plant environments (Note 23). This is particularly true of the coasts of the south of the island. Conflicts of use, the financial, land and ecological interests of municipalities, the State, nature conservation associations, inhabitants and private developers render a harmonious territorial structuring impossible. Having competencies that frequently overlap, the public bodies guaranteeing the legality of planning and development procedures are inclined to favour sectoral operations. However, in this situation of strong human footprint, the systemic approach would allow a much more controlled development. It (the global or systemic approach) implies taking into account all the biophysical and societal structures and functions of the territory in general and the coastlines in particular. Its aim is to estimate the latter's carrying capacity, their capacity for regulation as well as their ecological resilience (Figure 18).

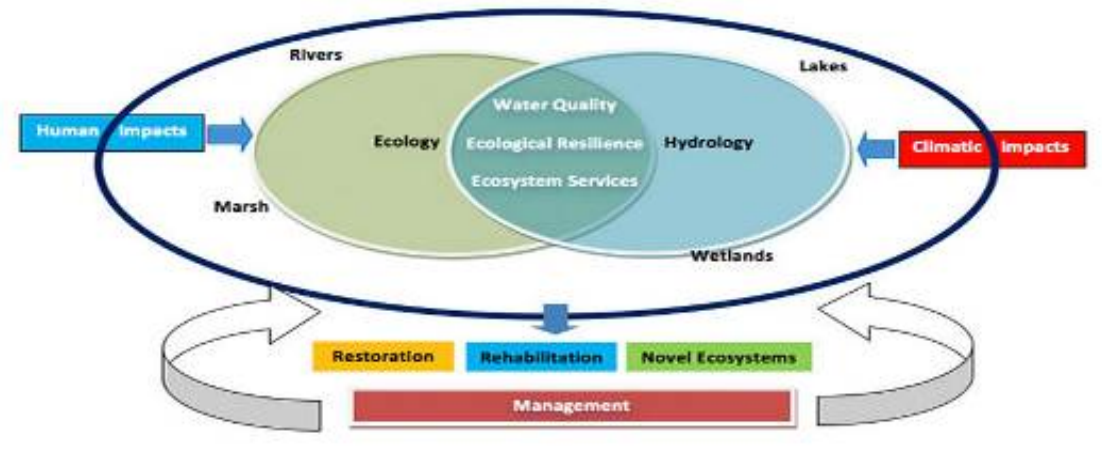

Figure 18. Wetland management and restoration strategies for promoting ecological resilience (Source: Federation of Australian Universities: research themes)

A database that integrates all the mesological, structural, architectural, specific, biocenotic and ecosystem characteristics of the floristic formations of coastal areas is, in this case, primordial. These spatial data in the form of maps will serve as evolutionary planning tools helping us, in the long term, to implement true sustainable development conditions. The use of coastal plant diversity is one of the main assets of economic development. It addresses the vegetation's ecological values which are expressed at so many levels of ecosystem integration: species, phytocenoses, geosystems and more widely landscapes. However, the natural fragility of this floristic diversity is accentuated by human activities on these lands subjected to climatic and telluric risks. Apart from global climate changes, one of the biggest crises to occur in the short term is biological. It is due to certain foreign species that will become invasive or invading and which prefer the open anthropized environments. Allochthonous plant species are common in private and public gardens. With the exception of Funtunmia elastica (Apocynaceae from tropical Africa), which territorially exhibits rather high individual densities, those that venture into the natural vegetation are marginal and develop very small populations. In general, the effects of global climate changes are likely to strongly affect the islands and particularly the small islands. As the sea level rise (due to the melting of glaciers and the expansion of the warmed ocean volume), 
potential tsunamis and increasingly dangerous climatic disturbances (which, after progressive submergence, will lead to new coast limits) will be accompanied by major ecosystem transformations. They have an impact on the spatial boundaries of ecosystems, species and biocenoses.

In reality, the means of protection, conservation and use depend on the environmental diagnosis which necessarily involves the inventory of ecosystem components and traditional tangible and intangible uses (Kimber, 1988). They are based on a landscapes classification in terms of their biological and aesthetic interests but also based on their vulnerability (Figure 17 and Annex 1). The ecosystems richest in plant forms are patrimonial and represent true laboratories for scientific research and resources for the future development, the ecological tourism in particular. This complex problem, which lies at the interface between societal dynamics and ecological dynamics, involves economic, cultural and social concerns. Within the framework of common objectives of systemic development, the results of fundamental and applied multidisciplinary research will guide the development policies. The sustainability of heritage ecosystems and their biological diversity imply the implementation of a management adapted to the constraints generated by the interaction of the "societal" and biophysical environments (Note 24) (Figures 19 and 20).

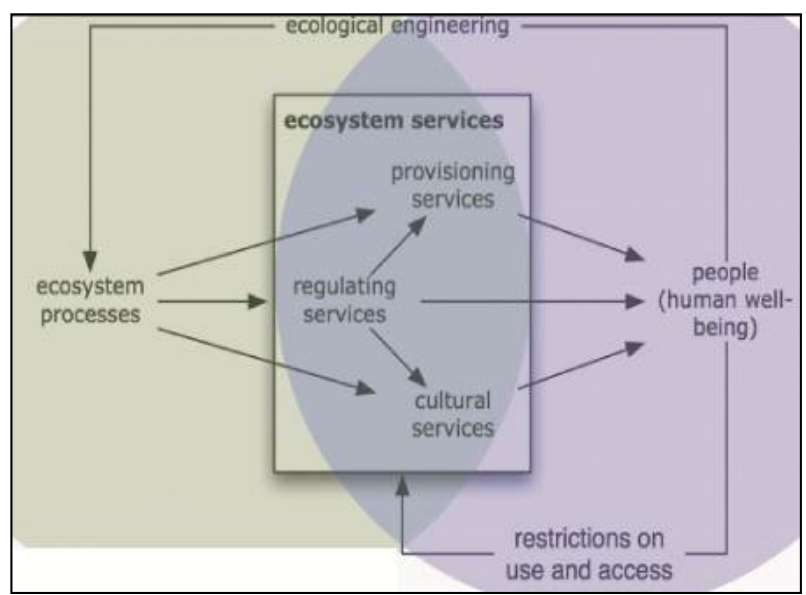

Figure 19. Ecosystem services: links between the social and ecological system (Source: Modified from Bennett, Peterson and Gordon, 2009)

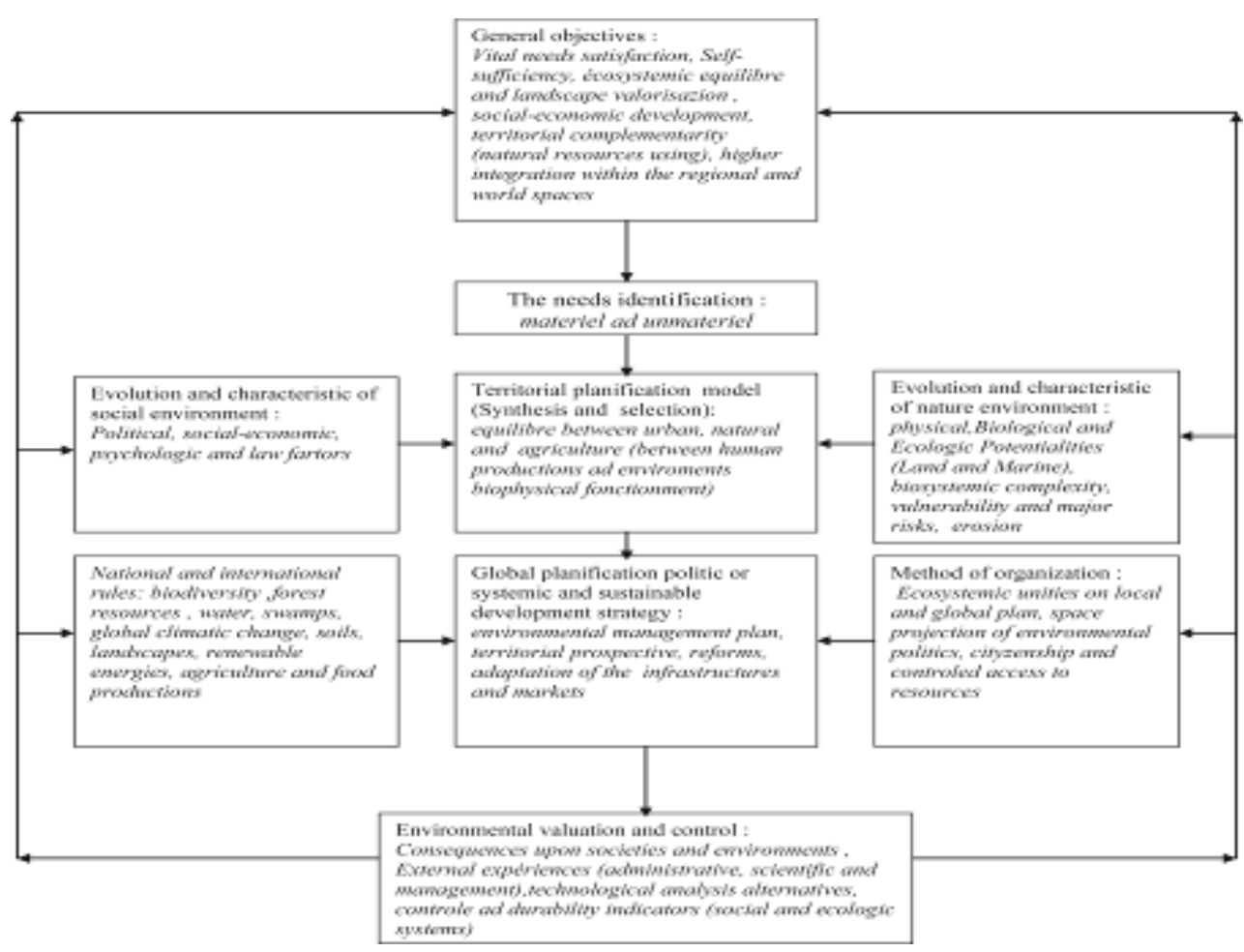

Figure 20. Territorial planning model including the landscape elements 


\section{Conclusion}

The small size of the territory, the high human density and the recurring natural hazards constitute major handicaps for the long-term protection of the many aspects of coastal vegetation. The locations, where the first inhabitants once settled, are today the home of most vital infrastructures. Industrial, tourist and traditional fishing units, as well as public and private buildings, share this space with contrasting geomorphology (Note 25) and form the basis of conflicts of use and interests. The co-operation between all administrative, scientific and technical powers is essential for the sustainable conservation of species, ecosystems and landscapes.

If, in the northern part, the more or less discontinuous floristic environments (Note 26) are preponderant, in the south the human productions are much more significant. Apart from the natural reserves, the Conservatoire du Littoral areas and the area of the fifty non-built geometric steps, everywhere else the vegetation has greatly decreased. Sometimes, it is reduced to low specific diversity islets. Despite permanent biotope artificialisation, the numerous biocenoses of the coast of Martinique form ecosystems of a high ecological quality that build exceptional landscapes. The existing littoral vegetation represents an "archipelago" of vegetal formations of different age, physiognomy, complexity, size and floristic composition. In contact with these small Caribbean islands, just like the first discoverers, today's tourists will surely wonder at this biological diversity (Note 27) at all levels of ecosystem integration (Note 28). In order to improve this insular coastal "tropical" nature whose landscapes represent strong markers, it seems important to restore the regressive natural environments inappropriate to the habitat, the agriculture and the various infrastructures.

\section{Acknowledgements}

We thank the Territorial Collectivity of Martinique (CTM: local government) which supported this research through financial subsidies and made possible the publication of this article.

\section{References}

Acevedo-Rodríguez, P., \& Strong, M. T. (2008). Floristic richness and affinities in the West Indies. The Botanical Review, 74(1), 5-36. https://doi.org/10.1007/s12229-008-9000-1

Alongi, D. M. (2008). Mangrove forests: resilience, protection from tsunamis, and responses to global climate change. Estuarine, Coastal and Shelf Science, 76(1), 1-13. https://doi.org/10.1016/j.ecss.2007.08.024

Bâ, A. M., \& Rivera-Ocasio, E. (2015). Genetic Diversity and Functional Traits of Pterocarpus officinalis Jacq. Associated with Symbiotic Microbial Communities in Caribbean Swamp Forests in Relation to Insular Distribution, Salinity and Flooding. Wetlands, 35(3), 433-442. https://doi.org/10.1007/s13157-015-0651-5

Baillard, K. (2016). The Effects of Anthropization on the Coastal Island Vegetation: The Example of the Mangrove Forest of the Bay of Fort-de-France (Martinique). International Journal of Recent Research and Review, 9(2), 1-14.

Beard, J. S. (1949). The natural vegetation of Windward and Leeward Islands. Oxford Forestry Mem.

Bennett, E. M., Peterson, G. D., \& Gordon, L. J. (2009) Understanding relationships among multiple ecosystem services. Ecology Letters, 12, 1394-1404. https://doi.org/10.1111/j.1461-0248.2009.01387.x

Bertran, P., Bonnissent, D., Imbert, D., Lozouet, P., Serrand, N., \& Stouvenot, C. (2004). Paléoclimat des Petites Antilles depuis 4000 ans BP: l'enregistrement de la lagune de Grand-Case à Saint-Martin. Comptes Rendus Geoscience, 336(16), 1501-1510. https://doi.org/10.1016/j.crte.2004.09.009

Bonnissent, D., Bertran, P., Galop, D., Imbert, D., \& Stouvenot, C. (1998). Chronologie des occupations précolombiennes de l'île de Saint-Martin (Petites Antilles) et relations avec les paléoenvironnements. In Twenty-fisrt Congress of the international association for caribbean archaeology (Vol. 1, pp. 20-30). University of the West Indies. Retrieved from https://halshs.archives-ouvertes.fr/halshs-00995384/document

Bouton J., (1640). Relation de l'établissement des français depuis l'an 1635 en l'île de la Martinique : l'une des Antilles de l'Amérique. Reprod. en fac. sim. de l'éd. de Paris: S. CRAMOISY (1640).

Brockway, L. H. (1979). Science and colonial expansion: the role of the British Royal Botanic Gardens. American Ethnologist, 6(3), 449-465. https://doi.org/10.1525/ae.1979.6.3.02a00030

Burke, L., Kura, Y., Kassem, K., Revenga, C., Spalding, M., McAllister, D., \& Caddy, J. (2001). Coastal ecosystems. Washington, DC: World Resources Institute. Retrieved from http://www.costabalearsostenible.es/PDFs/AMYKey\%20References_Indicators/PAGE_WRI.pdf

Cushman, J. H. (1995). Ecosystem-level consequences of species additions and deletions on islands." Islands (Springer Berlin Heidelberg), 135-147. https://doi.org/10.1007/978-3-642-78963-2_11 
Delawarde, J. B. (1935). Les défricheurs et les petits colons de la Martinique au XVIIe siècle. Paris : (s.n), (imp.R. Buffaut).

Ellison, A. M., \& Farnsworth, E. J. (1996). Anthropogenic disturbance of Caribbean mangrove ecosystems: past impacts, present trends, and future predictions. Biotropica, 549-565. https://doi.org/10.2307/2389096

Erlandson, J. M., \& Fitzpatrick, S. M. (2006). Oceans, islands, and coasts: current perspectives on the role of the sea in human prehistory. Journal of Island \& Coastal Archaeology, 1(1), 5-32. https://doi.org/10.1080/15564890600639504

Flower, J. M., \& Imbert, D. (2006). Recovery deficiency following tree mortality in mangroves of two Caribbean islands: field survey and statistical classification. Wetlands Ecology and Management, 14(2), 185-199. https://doi.org/10.1007/s11273-005-7683-1

Fressinet J.P. (1988). L'habitation de l'anse Couleuvre. C2 (mémoire de Maîtrise), Université Antilles Guyane.

Fricker, A., \& Forbes, D. L. (1988). A system for coastal description and classification. Coastal Management, 16(2), 111-137. https://doi.org/10.1080/08920758809362052

Hatzenberger, F. (1994). Paysages et végétations des Antilles. Paris, Karthala.

http://ijrrr.com/papers92/paper1The\%20Effects\%20of\%20Anthropization\%20on\%20the\%20Coastal\%20Island\% 20Vegetation-\%20The\%20Example\%20of\%20the\%20Mangrove\%20Forest\%20of\%20the\%20Bay\%20of\% 20Fort-de-France.pdf

Imbert, D., \& Delbé, L. (2006). Ecology of fire-influenced Cladium jamaicense marshes in Guadeloupe, Lesser Antilles. Wetlands, 26(2), 289-297. https://doi.org/10.1672/0277-5212(2006)26[289:eofcjm]2.0.co;2

Imbert, D., Bonhême, I., Saur, E., \& Bouchon, C. (2000). Floristics and structure of the Pterocarpus officinalis swamp forest in Guadeloupe, Lesser Antilles. Journal of Tropical Ecology, 55-68. https://doi.org/10.1017/s0266467400001267

Joseph, P. (1997). Dynamique, écophysiologie végétales en bioclimat sec à la Martinique (Doctoral dissertation, Thèse de doctorat nouveau régime, Université des Antilles et de la Guyane, Martinique, 941p.,(Annexes, 111p.).

Joseph, P. (2012). The vegetation of the Lesser Antilles: Floristic diversity and ecosystemic dynamics. International Journal of Environmental Studies, 69(5), 816-833. https://doi.org/10.1080/00207233.2012.715384

Joseph, P. (2015). The Final Stages of Vegetal Dynamics in the Lesser Antilles (A Few Theories). International Journal of Science and Research (IJSR), 4(11), 1151-1164. https://doi.org/10.21275/v4i11.nov151356

Joseph, P., \& Baillard, K. (2016). The Lesser Antilles, True Laboratories for the Study of Forest Systems the Evolution (from the Inventory of Plant Species to the Dynamics of the Anthropized Landscapes). Open Access Library Journal, 3(08), 1. https://doi.org/10.4236/oalib.1102969

Joseph, P., Pagney, F., \& Tanasi, M. (2003). Unités paysagères en bioclimat de transition dans le karst anthropisé des Grands-Fonds (Guadeloupe-Antilles françaises): In IXe Journées de Géographie Tropicale : Patrimoine et développement dans les pays tropicaux, Espaces Tropicaux, 18, 103-112.

Kimber, C. T. (1988). Martinique revisited. Texas University Press, College Station.

Labat, J. B. (1972-1974). Nouveau voyage aux Iles d'Amérique. Fort-de-France. Edition des Horizons Caraïbes, 4 Vol. (Réimpression de l'édition de 1742).

Li, X., Zhang, Z., Tan, H., Gao, Y., Liu, L., \& Wang, X. (2014). Ecological restoration and recovery in the wind-blown sand hazard areas of northern China: relationship between soil water and carrying capacity for vegetation in the Tengger Desert. Science China. Life Sciences, 57(5), 539-548. https://doi.org/10.1007/s11427-014-4633-2

Loveless, A. R. (1960). The vegetation of Antigua, West Indies. The Journal of Ecology, 495-527. https://doi.org/10.2307/2257330

Meur-Férec, C., Deboudt, P., \& Morel, V. (2008). Coastal risks in France: an integrated method for evaluating vulnerability. Journal of Coastal Research, 24(sp2), 178-189. https://doi.org/10.2112/05-0609.1

Mokhtar, B. (2013). Is Littoralization Reconfiguring the Omani Territory?. In Regionalizing Oman (pp. 217-225). Springer Netherlands. https://doi.org/10.1007/978-94-007-6821-5_13 
Moore, G. E., Gilmer, B. F., \& Schill, S. R. (2014). Distribution of mangrove habitats of Grenada and the Grenadines. Journal of Coastal Research, 31(1), 155-162. https://doi.org/10.2112/jcoastres-d-13-00187.1

Moreau, J. P. (1987). Un flibustier dans la mer des Antilles: 1618-1620. Manuscrit inédit du début du XVIIe siècle. Publ. par J.P.MOREAU, préf. de J. MEYER. Clamart : Collection BiBliogr.

Phillips, M. R., \& Jones, A. L. (2006). Erosion and tourism infrastructure in the coastal zone: Problems, consequences and management. Tourism https://doi.org/10.1016/j.tourman.2005.10.019

Reinhold-Castro, K. R., Fenelon, V. C., Rossi, R. M., Brito, J. E., Freitas, J. S., \& Teodoro, U. (2013). Impact of control measures and dynamics of sand flies in southern Brazil. Journal of Vector Ecology, 38(1), 63-68. https://doi.org/10.1111/j.1948-7134.2013.12009.x

Rochefort, C. (1667) Histoire naturelle des îles Antilles de l'Amérique. Lyon: C. Fourmy.

Schleupner, C. (2007). Spatial assessment of sea level rise on Martinique's coastal zone and analysis of planning frameworks for adaptation. Journal of Coastal Conservation, 11(2), 91-103. https://doi.org/10.1007/s11852-008-0010-2

Siegel, P. E., Jones, J. G., Pearsall, D. M., Dunning, N. P., Farrell, P., Duncan, N. A., ... Singh, S. K. (2015). Paleoenvironmental evidence for first human colonization of the eastern Caribbean. Quaternary Science Reviews, 129, 275-295. https://doi.org/10.1016/j.quascirev.2015.10.014

Tertre, J. P. (DU) (1667). L'histoire générale des Antilles habitées par les français. Vol. 1 \& 2, contenant tout ce qui s'est passé dans l'établissement des colonies françaises. Paris, Thomas Jolly.

Thibault de Chanvalon J. B. (1763). Voyage à la Martinique : contenant diverses observations sur la physique, l'histoire naturelle, l'agriculture, les moeurs et les voyages de cette île faite en 1751 et dans les années suivantes. Paris : CI. J.B. Bauche.

\section{Notes}

Note 1 The Amerindians were the first inhabitants of the West Indies: the first people were mainly hunters, gatherers and fishermen.

Note 2 The Land in many cases falls under private law and is subject to strong anthropogenic pressures.

Note 3 At municipal level "les P.L.U".

At departmental level, "departmental sensitive areas, whose associated tax would be used to finance integrated protection and use operations".

At regional level, "regional conservatories of natural spaces" and the Regional natural parks.

The State manages the nature reserves and the conservatory of the littoral. In addition, there is a whole series of protection measures regarding the quality of species and biotopes.

Note 4We can also observe an entire series of mixed forms with complex dynamics.

Note 5 The effects of climatic hazards conditioning the dynamics of the marine fluid are over-expressed due to anthropization.

Note 6 The dry sub-humid bioclimate is characterised by high sunshine, long drought (4-5 months), annual rainfall of less than $1500 \mathrm{~mm}$, low average cloud cover and vertisols.

Note 7 The wet sub-humid bioclimate is characterised by more abundant rains more spread out over time. The rainfall recession is much shorter and hardly exceeds three months. The annual rainfall ranges between 1800 and $2000 \mathrm{~mm}$.

Note 8 This forest type was very marginal in the prehistory of Martinique. However, some existing secondary forest groups today have similar characteristics.

Note 9 Edge or ecotone between sub-montane ombrophilous forest and seasonal rainforests, respectively conditioned by the wet and wet sub-humid bioclimates.

Note 10 This phenomenon existed in pre-colonial times.

Note 11 The middle and upper levels respectively harbour the tropical seasonal evergreen forest, the tropical sub-montane rainforest and the tropical montane rainforest. 
Note 12 The mornes are small hills.

Note 13 They are partly responsible for the disturbances observed today.

Note 14 In reality, these populations fashioned the plant cover in correlation with their different development stages.

Note 15 Very marginally, two other tree species Machaerium lunatum (Fabaceae) and Entada polystachya (Mimosaceae) can also be noted

Note 16 In the long term, this subunit is highly likely to disappear. One possible action would be the re-establishment of seasonal water transfers between the two subunits.

Note 17 This one is saxicole or litholphilous in nature.

Note 18 Especially those of the middle floor and more rarely of the upper floor.

Note 19 These various aspects of biological diversity are not exhaustive since their interaction modalities in terms of energy and matter exchange are not known.

Note 20 In fact, the regressive or progressive dynamics are not linear: it is a field of possible trajectories which is a function of the biophysical factors and the station history.

Note 21 The structural and functional characteristics of biophysical environments characterize the tropical islands.

Note 22 This is mainly prevalent on the littoral between the commune of Sainte-Luce and Marin (south of the island).

Note 23 In particular, the littoral law, the landscape law and the law on biodiversity

Note 24 Most of the planning documents are inoperative: SAR (Regional Planning Scheme) and SMV (Seabed Development Scheme), PLU (Local Plans, Urban Planning) etc.

Note 25 White sand, black sand and pebble beaches, rocky edges of varying gradients, cliffs, dryland strips and wet environments.

Note 26 Irrespective of their ecosystem potential.

Note 27 In general, due to the various facies of the geomorphological model leading to significant spatial differentiations in bioclimates, due to the anthropization modes not always equivalent between the different plant stages, the floristic and ecosystem expressions are very singular in space and in time.

Note 28 Hierarchical levels of organisation or complexity.

Annex 1. Characteristics of the inventoried Natural Monuments (coastal natural monuments are in red)

\begin{tabular}{|c|c|c|c|c|c|c|}
\hline No. & $\begin{array}{l}\text { Geosystems / } \\
\text { Vegetal formations / } \\
\text { Dynamic levels } \\
\end{array}$ & $\begin{array}{l}\text { Landscape } \\
\text { Interest }\end{array}$ & $\begin{array}{l}\text { Floristic } \\
\text { Interest }\end{array}$ & $\begin{array}{l}\text { Fauna } \\
\text { Interest }\end{array}$ & $\begin{array}{l}\text { Dynamic \& } \\
\text { Ecosystemic } \\
\text { Interest } \\
\end{array}$ & $\begin{array}{l}\text { Current Statutes \& } \\
\text { Protections } \\
/ \\
\text { Future management tool }\end{array}$ \\
\hline 1 & $\begin{array}{l}\text { North of Mount Pelée and the } \\
\text { Piton Mont-Conil and Morne Siberie volcanic } \\
\text { groups: A sector with all types of forest vegetation } \\
\text { (horizons and facies). This is a unique example of } \\
\text { the continuity of the vegetation cover, from the } \\
\text { coastline to the highest peaks. }\end{array}$ & +++++ & ++++ & +++ & +++++ & $\begin{array}{l}\text { Private forest } \\
\text { Registered site, } \\
\text { Conservatoire du littoral, } \\
\text { ZNIEFF / } \\
\text { Biosphere Reserve }\end{array}$ \\
\hline 2 & $\begin{array}{l}\text { Leyritz forest: } \\
\text { Tropical sub-montane rainforest of lower horizon }\end{array}$ & +++ & ++ & ++ & ++++ & $\begin{array}{l}\text { Private Forest } \\
\text { ZNIEFF / Biotope order, } \\
\text { Classified Wooded Area } \\
\text { (P.O.S), Protected Forest }\end{array}$ \\
\hline 3 & $\begin{array}{l}\text { Daydan forest: } \\
\text { Tropical sub-montane rainforest of lower horizon } \\
\text { advanced secondary with climax islands }\end{array}$ & ++ & ++++ & ++++ & ++++ & $\begin{array}{l}\text { Private Forest / Biotope } \\
\text { Order, Classified Wooded } \\
\text { Area (P.O.S), Protection } \\
\text { Forest }\end{array}$ \\
\hline 4 & $\begin{array}{l}\text { Morne Jacob, Bois Duhaumont, Desmornières } \\
\text { and Crassous:Tropical sub-montane rainforest to }\end{array}$ & ++++++ & ++++ & ++++ & ++++++ & $\begin{array}{l}\text { Regional state Forest, } \\
\text { ZNIEFF / }\end{array}$ \\
\hline
\end{tabular}




\begin{tabular}{|c|c|c|c|c|c|c|}
\hline & $\begin{array}{l}\text { tropical seasonal ombro-evergreen secondary } \\
\text { evolved forest integrating some climax units. }\end{array}$ & & & & & $\begin{array}{l}\text { Regional Conservatory of } \\
\text { Natural Areas, Northern } \\
\text { Natural Reserve }\end{array}$ \\
\hline 5 & $\begin{array}{l}\text { Mornes Mantoban and Patate: Sub-montane rain } \\
\text { forest and ombro-evergreen tropical seasonal } \\
\text { forests in progress towards the climax. Strong } \\
\text { presence of Talauma and Sloanea. }\end{array}$ & +++++ & +++ & ++++ & +++++ & $\begin{array}{l}\text { Private forest / } \\
\text { Regional Conservatory of } \\
\text { Natural Areas, Northern } \\
\text { Natural Reserve } \\
\end{array}$ \\
\hline 6 & $\begin{array}{l}\text { Rivière des Pitons, Piton Mitan, Morne Eclair, } \\
\text { Morne Cabillon, Morne Rouge; } \\
\text { Evergreen tropical seasonal forest of type and } \\
\text { upper horizons, late secondary forest with } \\
\text { remaining groups of the former climax. }\end{array}$ & +++++ & +++ & +++ & ++++ & $\begin{array}{l}\text { Private forest / } \\
\text { Regional Conservatory of } \\
\text { Natural Areas, Northern } \\
\text { Natural Reserve }\end{array}$ \\
\hline 7 & $\begin{array}{l}\text { Le Grand Plateau: Tropical sub-montane } \\
\text { rainforest with Dacryodes, Tapura, Sloanea. }\end{array}$ & +++++ & +++++ & ++++ & +++++ & $\begin{array}{l}\text { Regional -state Forest, } \\
\text { ZNIEFF / } \\
\text { Regional Conservatory of } \\
\text { Natural Areas, Northern } \\
\text { Natural Reserve } \\
\end{array}$ \\
\hline 8 & $\begin{array}{l}\text { Morne Piquet: } \\
\text { Upper transition forest Ombro-sub-montane } \\
\text { rainforest, significant population of Podocarpus } \\
\text { coriaceus. }\end{array}$ & ++++++ & +++++ & +++ & +++++ & $\begin{array}{l}\text { Regional -state Forest, } \\
\text { ZNIEFF / } \\
\text { Regional Conservatory of } \\
\text { Natural Areas, Northern } \\
\text { Natural Reserve }\end{array}$ \\
\hline 9 & $\begin{array}{l}\text { Morne des Olives forest: tropical sub-montane } \\
\text { rainforest, sub-climactic }\end{array}$ & ++++ & ++++ & +++ & ++++++ & $\begin{array}{l}\text { Regional -state Forest, } \\
\text { ZNIEFF / } \\
\text { Regional Conservatory of } \\
\text { Natural Areas, Northern } \\
\text { Natural Reserve }\end{array}$ \\
\hline 10 & $\begin{array}{l}\text { Plateau Concorde, Bois Concorde, Plateau Clark, } \\
\text { Plateau west of Colson Hopital: Sub-montane } \\
\text { tropical sub-climactic rainforest to climax. } \\
\text { Forêt Fond Georges: } \\
\text { Ombro-evergreen seasonal tropical and evergreen } \\
\text { tropical seasonal, secondary structured forest with } \\
\text { remaining climax species }\end{array}$ & +++++ & ++++ & +++ & +++++ & $\begin{array}{l}\text { Regional -state Forest, } \\
\text { Private Forest, ZNIEFF, / } \\
\text { Regional Conservatory of } \\
\text { Natural Areas, Northern } \\
\text { Natural Reserve }\end{array}$ \\
\hline 11 & $\begin{array}{l}\text { Bois La Roche: Seasonal tropical } \\
\text { ombro-evergreen forest and seasonal tropical } \\
\text { evergreen forest, including advanced climax units }\end{array}$ & ++++++ & ++++++ & +++ & ++++++++ & $\begin{array}{l}\text { Private Forest, Biotope } \\
\text { Order, Classified Wooded } \\
\text { Area, Protection Forest, } \\
\text { ZNIEFF / Regional } \\
\text { Conservatory of Natural } \\
\text { Areas, Northern Natural } \\
\text { Reserve }\end{array}$ \\
\hline 12 & $\begin{array}{l}\text { Morne Césaire: } \\
\text { Seasonal tropical ombro-evergreen forest and } \\
\text { tropical seasonal evergreen forest, structured } \\
\text { secondary in expansion, with a strong } \\
\text { regenerative potential of climax species } \\
\text { Plateau Perdrix, Morne Baptiste: Tropical } \\
\text { sub-montane rain forest, advanced secondary, } \\
\text { sub-climactic and climactic. }\end{array}$ & $\begin{array}{c}++++ \\
++++ \\
++++2\end{array}$ & $\begin{array}{l}+++ \\
++++++\end{array}$ & 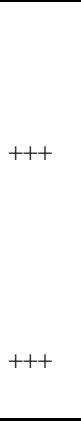 & $\begin{array}{c}++++ \\
+++++ \\
+++4\end{array}$ & $\begin{array}{l}\text { Regional - state forest, } \\
\text { Private forest, ZNIEFF / } \\
\text { Regional Conservatory of } \\
\text { Natural Areas, Northern } \\
\text { Natural Reserve }\end{array}$ \\
\hline 13 & $\begin{array}{l}\text { Bois Pointe Rouge: } \\
\text { Seasonal tropical evergreen forest, structured } \\
\text { secondary initiating a strong regeneration of } \\
\text { Cassipourea, and of Garcinia; Presence of }\end{array}$ & +++++ & ++++ & +++ & +++++ & $\begin{array}{l}\text { Conservatoire du Littoral, } \\
\text { Registered site, Coastal State } \\
\text { Forest ZNIEFF / } \\
\text { Biotope Order, Classified } \\
\end{array}$ \\
\hline
\end{tabular}




\begin{tabular}{|c|c|c|c|c|c|c|}
\hline & Hymenaea courbaril of important size. & & & & & $\begin{array}{l}\text { Wooded Area (P.O.S), } \\
\text { Protection forest, Natural } \\
\text { Reserve }(*)\end{array}$ \\
\hline 14 & $\begin{array}{l}\text { Morne de la Regale: } \\
\text { Seasonal tropical evergreen forest of lower } \\
\text { horizon and very xeric facies, young secondary }\end{array}$ & ++++ & ++ & ++ & +++ & $\begin{array}{l}\text { Registered site, ZNIEFF, } \\
\text { Coastal State Forest / } \\
\text { Biotope order, Classified } \\
\text { Wooded Area, Protection } \\
\text { Forest, Natural Reserve }(*)\end{array}$ \\
\hline 15 & $\begin{array}{l}\text { Pointe Jean-Claude: } \\
\text { Seasonal tropical evergreen forest of lower } \\
\text { horizon and very xeric facies, advanced secondary } \\
\text { with a large population of rare climax species as } \\
\text { Eugenia tapacumensis, Hymenaea courbaril, } \\
\text { Sidéroxylon Foetidissimum. }\end{array}$ & ++++ & ++++ & + & ++++++ & $\begin{array}{l}\text { Coastal State Forest, } \\
\text { ZNIEFF, } \\
\text { Biotope Order, Classified } \\
\text { Wooded Area (P.O.S), } \\
\text { Protection Forest, Natural } \\
\text { Reserve }\left(^{*}\right)\end{array}$ \\
\hline 16 & $\begin{array}{l}\text { Bois Pothau, Pointe Banane, Mansarde Rancée: } \\
\text { Seasonal tropical evergreen forest of typical and } \\
\text { lower horizon, structured and advanced secondary } \\
\text { forest possessing remaining taxa of the former } \\
\text { climax forest (Sideroxylon foetidissimum). }\end{array}$ & +++++ & +++++ & + & ++++ & $\begin{array}{l}\text { Private forest, ZNIEFF, } \\
\text { Biotope Order, Classified } \\
\text { Wooded Area (P.O.S), } \\
\text { Protection Forest, Natural } \\
\text { Reserve }(*)\end{array}$ \\
\hline 17 & $\begin{array}{l}\text { Bois de Terreville (Riviere Case Navire): } \\
\text { Seasonal tropical evergreen forest of typical and } \\
\text { lower horizon, riparian facies, structured } \\
\text { secondary forest, presence of rare species } \\
\text { (Cupania,Acrocomia). }\end{array}$ & ++++ & ++++ & + & ++++ & $\begin{array}{l}\text { Private forest, ZNIEFF / } \\
\text { Biotope Order, Classified } \\
\text { Wooded Area (P.O.S), } \\
\text { Protection Forest, Natural } \\
\text { Reserve }(*)\end{array}$ \\
\hline 18 & $\begin{array}{l}\text { Morne Valentin: } \\
\text { Seasonal tropical evergreen forest of typical and } \\
\text { lower horizon, xeric facies, structured secondary } \\
\text { forest, presence of rare species (Anthurium } \\
\text { acaule, Coccothrinax Barbadensis, Sideroxylon } \\
\text { foetidissimum) }\end{array}$ & ++++ & ++++ & + & ++ & $\begin{array}{l}\text { Private forest, ZNIEFF / } \\
\text { Biotope Order, Classified } \\
\text { Wooded Area (P.O.S), } \\
\text { Protection Forest, Southern } \\
\text { Natural Reserve (*) }\end{array}$ \\
\hline 19 & $\begin{array}{l}\text { Vauclin Mountain: } \\
\text { Seasonal tropical ombro-evergreen and seasonal } \\
\text { tropical evergreen forest of typical and lower } \\
\text { horizon, young secondary, structured and } \\
\text { advanced, including climax species (Eugenia } \\
\text { biflora, Sloanea dentata), Presence of rare species } \\
\text { (Picrasma exelsa, Crateva Tapia) }\end{array}$ & +++++ & ++++++ & ++++ & ++++++ & $\begin{array}{l}\text { ZNIEFF / } \\
\text { Biotope Order, Classified } \\
\text { Wooded Area (P.O.S), } \\
\text { Protection Forest, Southern } \\
\text { Natural Reserve }(*)\end{array}$ \\
\hline 20 & $\begin{array}{l}\text { Bois de Charles: } \\
\text { Tropical seasonal ombro-evergreen forest, } \\
\text { secondary advanced (sole representative of this } \\
\text { forest vegetation which formerly covered a good } \\
\text { part of the south central area), high floristic } \\
\text { diversity. }\end{array}$ & ++++ & ++++++ & +++ & ++++++ & $\begin{array}{l}\text { Private forest, ZNIEFF / } \\
\text { Biotope Order, Classified } \\
\text { Wooded Area (P.O.S), } \\
\text { Protection Forest, Southern } \\
\text { Natural Reserve }\left(^{*}\right)\end{array}$ \\
\hline 21 & $\begin{array}{l}\text { Mornes Guardier,Du Riz, Founerey, Burgot, Belle } \\
\text { Vue, Savon, Des Peres and Boiss Michel: } \\
\text { Seasonal tropical evergreen forest of upper, } \\
\text { typical and lower horizon, young secondary, } \\
\text { structured, with some islands and climax species. }\end{array}$ & +++++++ & +++++++ & ++++ & +++++++ & $\begin{array}{l}\text { Private forest, ZNIEFF / } \\
\text { Biotope Order, Classified } \\
\text { Wooded Area (P.O.S), } \\
\text { Protection Forest, Southern } \\
\text { Natural Reserve }\left(^{*}\right) \\
\end{array}$ \\
\hline 22 & $\begin{array}{l}\text { Gros Morne, Gallochat, Pointe Blanche: Seasonal } \\
\text { tropical evergreen forest of lower horizon, very } \\
\text { xeric facies, young secondary }\end{array}$ & +++++ & +++ & ++ & +++++ & $\begin{array}{l}\text { Private forest and coastal } \\
\text { State forest, ZNIEFF / } \\
\text { Biotope Order, Classified } \\
\text { Wooded Area (P.O.S), } \\
\text { Protection Forest, Southern } \\
\text { Natural Reserve }(*)\end{array}$ \\
\hline
\end{tabular}




\begin{tabular}{|c|c|c|c|c|c|c|}
\hline 23 & $\begin{array}{l}\text { Cap Salomon, Morne reduit, Anse du Four: } \\
\text { Seasonal tropical evergreen forest of lower } \\
\text { horizon, very xeric facies, young secondary }\end{array}$ & ++++++ & +++ & ++ & ++++ & $\begin{array}{l}\text { Private forest and coastal } \\
\text { state forest, Conservatoire du } \\
\text { littoral, ZNIEFF / } \\
\text { Biotope Order, Classified } \\
\text { Wooded Area (P.O.S), } \\
\text { Protection Forest, Southern } \\
\text { Natural Reserve }\left(^{*}\right) \\
\end{array}$ \\
\hline 24 & $\begin{array}{l}\text { Morne Camp: } \\
\text { Ombro-evergreen seasonaltropical and evergreen } \\
\text { seasonal tropical Forest, secondary young and } \\
\text { structured }\end{array}$ & +++++ & +++ & +++ & ++++ & $\begin{array}{l}\text { Private forest, ZNIEFF / } \\
\text { Biotope Order, Classified } \\
\text { Wooded Area (P.O.S), } \\
\text { Protection Forest, Southern } \\
\text { Natural Reserve }\left(^{*}\right)\end{array}$ \\
\hline 25 & $\begin{array}{l}\text { Ravine Saint-Pierre, Mornes Prefontaine and } \\
\text { d'Orient: } \\
\text { Seasonal tropical evergreen forest of typical and } \\
\text { lower horizon, young secondary, structured and } \\
\text { advanced, presence of climax groups }\end{array}$ & +++++ & +++++ & ++ & +++++ & $\begin{array}{l}\text { Private forest, ZNIEFF / } \\
\text { Biotope Order, Classified } \\
\text { Wooded Area (P.O.S), } \\
\text { Protection Forest, Southern } \\
\text { Natural Reserve }\left(^{*}\right) \\
\end{array}$ \\
\hline 26 & $\begin{array}{l}\text { Rocher Zombi: } \\
\text { Tropical seasonal Ombro-evergreen forest and } \\
\text { tropical seasonal evergreen forest of typical and } \\
\text { lower horizon, secondary young, structured and } \\
\text { advanced having sub-climax or sylvatic } \\
\text { communities }\end{array}$ & +++++ & ++++++ & +++ & ++++++ & $\begin{array}{l}\text { Private forest, ZNIEFF / } \\
\text { Biotope Order, Classified } \\
\text { Wooded Area (P.O.S), } \\
\text { Protection Forest, Southern } \\
\text { Natural Reserve }{ }^{*} \text { ) }\end{array}$ \\
\hline & $\begin{array}{l}\text { Forêt Domaniale du Marin, hills above La Source } \\
\text { and Quatre Chemins: } \\
\text { Evergreen tropical seasonal forest of lower } \\
\text { horizon and very xeric facies, young secondary, } \\
\text { presence of rare species installed and in } \\
\text { regeneration (Canella winterana (Structuring), } \\
\text { Sideroxylon foetidissimum) }\end{array}$ & +++++ & +++++ & + & ++++ & $\begin{array}{l}\text { Private forest / } \\
\text { Biotope Order, Classified } \\
\text { Wooded Area (P.O.S), } \\
\text { Protection Forest, Southern } \\
\text { Natural Reserve }\left(^{*}\right)\end{array}$ \\
\hline 27 & $\begin{array}{l}\text { LA Fouquette and above Grand Fond: } \\
\text { Evergreen tropical seasonal forest of lower } \\
\text { horizon and very xeric facies, secondary } \\
\text { structured and advanced or sub-climactic } \\
\text { composed of climax groups (Sideroxylon } \\
\text { foetidissimum, Coccothrinax barbadensis) }\end{array}$ & ++++++ & ++++++ & + & +++++ & $\begin{array}{l}\text { Private forest / } \\
\text { Biotope Order, Classified } \\
\text { Wooded Area (P.O.S), } \\
\text { Protection Forest, Southern } \\
\text { Natural Reserve }\left(^{*}\right)\end{array}$ \\
\hline 28 & $\begin{array}{l}\text { Pointe du Vauclin: } \\
\text { Seasonal tropical evergreen forest of lower } \\
\text { horizon and very xeric facies, young secondary, } \\
\text { with Tabebuia heterophylla, Lonchocarpus } \\
\text { violaceus, } \\
\text { Bursera simaruba }\end{array}$ & ++++++ & + & + & ++ & $\begin{array}{l}\text { Private Forest and Coastal } \\
\text { state forest, ZNIEFF / } \\
\text { Biotope Order, Classified } \\
\text { Wooded Area (P.O.S), } \\
\text { Protection Forest, Southern } \\
\text { Natural Reserve }\left(^{*}\right) \\
\end{array}$ \\
\hline 29 & $\begin{array}{l}\text { Bay of Massy-Massy: } \\
\text { Colluvial mangrove forest }\end{array}$ & +++++++ & ++ & +++ & ++++ & $\begin{array}{l}\text { Biotope order, Classified } \\
\text { Wooded Area (P.O.S), }(*) \\
\end{array}$ \\
\hline 30 & $\begin{array}{l}\text { Pointe Macré, Grand Macabou, Petit Macabou: } \\
\text { Seasonal tropical evergreen forest of lower } \\
\text { horizon and very xeric facies, inland area, } \\
\text { structured secondary; Colluvial mangrove forest }\end{array}$ & ++++++ & ++ & +++++ & +++++ & $\begin{array}{l}\text { ZNIEFF / Biotope Order, } \\
\text { Classified Wooded Area, } \\
\text { Protection Forest, Southern } \\
\text { split Natural Reserve }\left(^{*}\right) \\
\end{array}$ \\
\hline 31 & $\begin{array}{l}\text { Mornes Larcher and Clochette: Seasonal tropical } \\
\text { evergreen forest of lower horizon and very xeric } \\
\text { facies, young secondary to structured, presence of } \\
\text { rare species }\end{array}$ & ++++++ & ++++ & +++ & ++++ & $\begin{array}{l}\text { Conservatoire du littoral, } \\
\text { Private Forest, ZNIEFF / } \\
\text { Biotope Order, Classified } \\
\text { Wooded Area, Protection } \\
\text { Forest, Southern split } \\
\text { Natural Reserve }(*)\end{array}$ \\
\hline & $\begin{array}{l}\text { Morne Aca: Tropical seasonal evergreen forest of } \\
\text { typical and lower horizon and xeric facies, young }\end{array}$ & & & & & $\begin{array}{l}\text { Private forest, Registered } \\
\text { site, ZNIEFF / Biotope order }\end{array}$ \\
\hline
\end{tabular}




\begin{tabular}{|c|c|c|c|c|c|c|}
\hline 32 & $\begin{array}{l}\text { secondary, structured and advanced, integrating } \\
\text { structured and late tropical seasonal } \\
\text { ombro-evergreen groups, presence of a large } \\
\text { number of rare or infrequent species. }\end{array}$ & +++++++ & ++++++ & ++++ & +++++++ & $\begin{array}{l}\text { Classified wooded area, } \\
\text { Protection forest, Southern } \\
\text { split nature reserve }(*)\end{array}$ \\
\hline 33 & $\begin{array}{l}\text { Mornes Caritan, Jolicoeur, North and South } \\
\text { America, Pointe Dunkerque: Seasonal tropical } \\
\text { evergreen forest of lower horizon and extreme } \\
\text { xeric facies, young secondary and structured, } \\
\text { presence of rare species (Maclura tinctoria) }\end{array}$ & +++++++ & +++++ & ++++ & +++++ & $\begin{array}{l}\text { Private Forest, ZNIEFF / } \\
\text { Biotope Decree, Classified } \\
\text { Wooded Area (P.O.S), } \\
\text { Protection Forest, Southern } \\
\text { split Natural Reserve }(*), \\
\text { Conservatoire du littoral }\end{array}$ \\
\hline 34 & $\begin{array}{l}\text { The limestones hills of Sainte-Anne: Seasonal } \\
\text { tropical evergreen forest of lower horizon and } \\
\text { very xeric facies, structured secondary, advanced, } \\
\text { composed of climax structuring species }\end{array}$ & +++++++ & +++++ & +++ & ++++++ & $\begin{array}{l}\text { Private forest, Registered } \\
\text { site, ZNIEFF / Biotope } \\
\text { order, Classified wooded } \\
\text { area, Protection forest, } \\
\text { Southern split nature reserve } \\
(*)\end{array}$ \\
\hline 35 & $\begin{array}{l}\text { Mangrove, coastal vegetation: Seasonal tropical } \\
\text { evergreen forest of lower horizon and extremely } \\
\text { xeric facies, young secondary and pre-forest units }\end{array}$ & +++++ & +++ & ++++ & +++ & $\begin{array}{l}\text { Coastal State Forest, } \\
\text { Registered Site / Biotope } \\
\text { Order, Classified Wooded } \\
\text { Area, Protection Forest, } \\
\text { Southern split Natural } \\
\text { Reserve }\left(^{*}\right)\end{array}$ \\
\hline 36 & $\begin{array}{l}\text { Morne des Petrifications: Seasonal tropical } \\
\text { evergreen forest of lower horizon and extreme } \\
\text { xeric facies, young secondary and pre-forest units }\end{array}$ & +++ & + & + & +++ & $\begin{array}{l}\text { Registered site } \\
\text { Biotope order }\end{array}$ \\
\hline
\end{tabular}

(*): Regional Conservatory of Natural Areas / ZNIEFF: Natural areas of iEcological, floristic and faunistic interests/(+): Importance of the descriptor

\section{Copyrights}

Copyright for this article is retained by the author(s), with first publication rights granted to the journal.

This is an open-access article distributed under the terms and conditions of the Creative Commons Attribution license (http://creativecommons.org/licenses/by/4.0/). 